\title{
Climatology of new particle formation at Izaña mountain GAW observatory in the subtropical North Atlantic
}

\author{
M. I. García ${ }^{1,2}$, S. Rodríguez ${ }^{1}$, Y. González ${ }^{1}$, and R. D. García ${ }^{1,3}$ \\ ${ }^{1}$ Izaña Atmospheric Research Centre, AEMET Joint Research Unit of CSIC "Studies on Atmospheric Pollution”, La Marina \\ 20, Planta 6, E38071, Santa Cruz de Tenerife, Canary Islands, Spain \\ ${ }^{2}$ Department of Analytical Chemistry, Nutrition and Food Science, University of La Laguna, Avda. Astrofísico Fco. Sánchez \\ s/n, 38200, La Laguna, Tenerife, Canary Islands, Spain \\ ${ }^{3}$ Atmospheric Optic Group, University of Valladolid (GOA, UVA), Paseo de Belén 7, 47011, Valladolid, Spain
}

Correspondence to: M. I. García (isabel_garciaalvarez@hotmail.es)

Received: 20 August 2013 - Published in Atmos. Chem. Phys. Discuss.: 13 September 2013

Revised: 25 February 2014 - Accepted: 27 February 2014 - Published: 17 April 2014

\begin{abstract}
A climatology of new particle formation (NPF) events at high altitude in the subtropical North Atlantic is presented. A 4-year data set (June 2008-June 2012), which includes number size distributions $(10-600 \mathrm{~nm})$, reactive gases $\left(\mathrm{SO}_{2}, \mathrm{NO}_{\mathrm{x}}\right.$, and $\left.\mathrm{O}_{3}\right)$, several components of solar radiation and meteorological parameters, measured at Izaña Global Atmosphere Watch (GAW) observatory (2373 m above sea level; Tenerife, Canary Islands) was analysed. NPF is associated with the transport of gaseous precursors from the boundary layer by orographic buoyant upward flows that perturb the low free troposphere during daytime. On average, $30 \%$ of the days contained an NPF event. Mean values of the formation and growth rates during the study period were $0.46 \mathrm{~cm}^{-3} \mathrm{~s}^{-1}$ and $0.42 \mathrm{~nm} \mathrm{~h}^{-1}$, correspondingly. There is a clearly marked NPF season (May-August), when these events account for 50-60\% of the days per month. Monthly mean values of the formation and growth rates exhibit higher values in this season, $0.49-0.92 \mathrm{~cm}^{-3} \mathrm{~s}^{-1}$ and $0.48-0.58 \mathrm{~nm} \mathrm{~h}^{-1}$, respectively. During NPF events, $\mathrm{SO}_{2}$, UV radiation and upslope winds showed higher values than during non-events. The overall data set indicates that $\mathrm{SO}_{2}$ plays a key role as precursor, although other species seem to contribute during some periods. Condensation of sulfuric acid vapour accounts for most of the measured particle growth during most of the year $(\sim 70 \%)$, except for some periods. In May, the highest mean growth rates $\left(\sim 0.6 \mathrm{~nm} \mathrm{~h}^{-1}\right)$ and the lowest contribution of sulfuric acid $(\sim 13 \%)$ were measured, suggesting a significant involvement of other condensing vapours. The $\mathrm{SO}_{2}$ availability seems also to be the
\end{abstract}

most influencing parameter in the year-to-year variability in the frequency of NPF events. The condensation sink showed similar features to other mountain sites, showing high values during NPF events. Summertime observations, when Izaña is within the Saharan Air Layer, suggest that dust particles may play a significant role acting as coagulation sink of freshly formed nucleation particles. The contribution of dust particles to the condensation sink of sulfuric acid vapours seems to be modest ( $\sim 8 \%$ as average). Finally, we identified a set of NPF events in which two nucleation modes, which may evolve at different rates, occur simultaneously and for which further investigations are necessary.

\section{Introduction}

The growth of nucleated clusters is an important source of atmospheric aerosols (Kulmala, 2003). It is considered that the so-called new particle formation (NPF) is a two-step (decoupled) process: nucleation and growth. It has been proposed that the nucleation of sulfuric acid gas molecules results in the formation of clusters $(<2 \mathrm{~nm}$ size; Kulmala et al., 2006; Kulmala and Kerminen, 2008) that are simultaneously being stabilized by amines, ammonia, or organic vapours (Kulmala et al., 2013). Under certain scenarios these clusters are activated in such a way that they grow up to result in stable aerosols with a size $\geq 50 \mathrm{~nm}$ (e.g. during the socalled "banana-type" growth events). Processes involved in the NPF (nucleation and growth up to stable sizes) are not 
fully understood. For the first phase, or nucleation, the most studied mechanisms are binary (water-sulfuric acid), ternary (water-sulfuric acid-ammonia) and ion-induced nucleation (see the Kulmala, 2003, discussion), but fail to explain field observations. Semi-empirical new mechanisms such as cluster activation and kinetic nucleation have been developed to explain the observed measurements (Kulmala et al., 2006; Laakso et al., 2004; Metzger et al., 2010). For the second phase, or growth, the proposed mechanisms include condensation of sulfuric acid - sulfate and organic vapours (Laaksonen et al., 2008; Kulmala et al., 2013).

Understanding how nucleated clusters and particles grow is important for studying the influence of aerosols on climate, including feedbacks (IPCC, 2007). This influence depends on particle size. Nucleation not followed by growth processes (e.g. bursts, also so-called "apple"-type events) typically results in high concentrations of particles $<20 \mathrm{~nm}$ size. These particles have a short lifetime ( $\sim$ hours), have a low ability to act as cloud condensation nuclei (McFiggans et al., 2006) and exhibit Rayleigh scattering features (as gases). In contrast, accumulation mode particles $(100-1000 \mathrm{~nm})$ are longlived ( $\sim$ few weeks), are good condensation nuclei and scatter light more efficiently. Because of the influence of thermodynamic variables (e.g. $T$ and $\mathrm{RH}$ ), UV radiation and meteorology on the NPF processes, climate may also affect NPF. Emission rates of gaseous precursors also play a key role. The decadal decrease (2001-2010) in the total particle number concentration (a metric dominated by particles $<20 \mathrm{~nm}$ ) observed at background and remote sites in Europe, North America and the Pacific has been attributed to a decrease of anthropogenic emissions of gaseous precursors (Asmi et al., 2012). In contrast, Dal Maso et al. (2005) observed how the frequency of NPF events increased from 1998 to 2003 in the Finnish boreal forest.

Long-term studies ( $\geq 1 \mathrm{yr}$ ) on NPF, which include the determination of the new particle formation rate (FR) and growth rate (GR), at mountain sites that reach the free troposphere are scarce (Fig. 1; see also Kulmala et al., 2004). These long-term studies have mostly been performed in the continental boundary layer (e.g. Birmili and Wiedensohler, 2000; Dal Maso et al., 2005; Hamed et al., 2007). Studies of NPF at mountain sites are of interest for several reasons. Because mountain upslope winds are frequently linked to high ultrafine particle concentrations (Weber et al., 1995; Venzac et al., 2008), elevated mounts may act as source regions for new particles in the free troposphere (FT), where these grown particles may experience long-range transport due to the much higher wind speeds and the longer lifetime of particles than in the boundary layer.

The objective of this work is to study the origin and processes that influence the NPF at high altitude in the subtropical North Atlantic. We analysed and interpreted the variability in the NPF frequency, growth rates and formation rates, and estimated the contribution of sulfuric acid to particle growth. As the study region is within the Saharan Air Layer
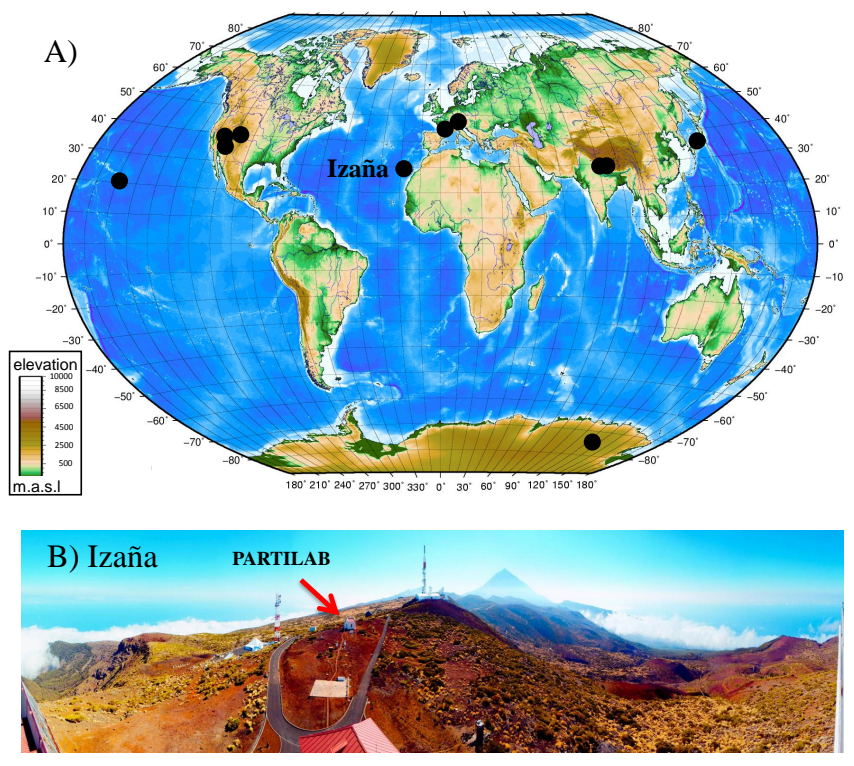

Fig. 1. (A) Global map highlighting the location of Izaña and of other high-altitude observatories where studies on NPF have been performed. From west to east: Mauna Loa, Hawaii (3400 m a.s.l.; Weber et al., 1995, 1999); Storm Peak Laboratory, Colorado (3210 ma.s.l.; Hallar et al., 2011); Mount Lemmon, Arizona (2700 ma.s.l.; Shaw et al., 2007); Rocky Mountains, Colorado (2900 ma.s.1.; Boy et al., 2008); Izaña, Tenerife (2373 m a.s.1.; this study); Puy de Dôme, France (1465 ma.s.l.; Venzac et al., 2007; Boulon et al., 2011); Jungfraujoch, Swiss Alps (3580 m a.s.l.; Boulon et al., 2010); Mukteshwar, Indian Himalayas (2180 m a.s.1.; Neitola et al., 2011); Pyramid, Nepal (5079 m a.s.l.; Venzac et al., 2008); Norikura, Japan (2770 m a.s.l.; Nishita et al., 2008); and Dome C, Antarctica (3200 m a.s.1.; Järvinen et al., 2013). (B) View of the PARTILAB (particles laboratory) from the Izaña observatory main building.

in summer, we also investigated how dust particles may influence NPF.

\section{Methodology}

\subsection{Study area}

Izaña Global Atmosphere Watch (GAW) observatory $\left(16^{\circ} 29^{\prime} 58^{\prime \prime} \mathrm{W}, 28^{\circ} 18^{\prime} 32^{\prime \prime} \mathrm{N}\right)$ is located in Tenerife island, at $2373 \mathrm{~m}$ a.s.l (Fig. 1a). The observatory (Fig. 1b) remains almost permanently above the marine stratocumulus layer typical of the subtropical oceans. NW dry subsiding airflows dominate throughout the year except in summer, when they are frequently alternated with SE airflows from North Africa. Below the stratocumulus layer, the humid and cool NNE trade winds dominate. The development of orographic thermal-buoyant upward flows during daytime results in the upward transport of water vapour and trace gases emitted at low altitudes by biogenic and anthropogenic sources (see details in Rodríguez et al., 2009). 


\subsection{Measurements}

This study is based on a 4 yr data set (June 2008-June 2012) of particle size distributions $(10-600 \mathrm{~nm})$, reactive gases $\left(\mathrm{SO}_{2}, \mathrm{NO}_{\mathrm{x}}, \mathrm{O}_{3}\right)$, meteorological parameters (temperature, humidity, water vapour, wind speed, wind direction) and radiation (global, direct, diffuse, UV-B, UV-A).

\subsubsection{Particle size distribution}

Particle size distribution within the range $10-600 \mathrm{~nm}$ was measured with a TSI $^{\mathrm{TM}}$ Scanning Mobility Particle Sizer (SMPS, model 3996). Two different condensation particle counters (CPCs) were used as detectors: a CPC-3025A from June 2008 to March 2009 and a CPC-3010 from March 2009 on. These instruments have been subjected to several quality assurance and quality control activities. The $50 \%$ efficiency diameters $\left(\mathrm{Dp}_{50}\right)$ were determined in the World Calibration Centre for Aerosol Physics (WCCAP, Institute for Tropospheric Research, Leipzig, Germany): $2.4 \mathrm{~nm}$ for the CPC-3025A unit (SN: 1160; September 2002) and $9.6 \mathrm{~nm}$ for the CPC-3010 unit (SN: 70431239; September 2011). The SMPS was intercompared, measuring ambient air aerosol, with similar TSI $^{\mathrm{TM}}$ SMPS instruments in April 2010 and November 2012 within the REDMAAS network (www. redmaas.com; Gómez-Moreno et al., 2013). In these exercises the sizing accuracy was also assessed with monodisperse polystyrene latex spheres of 80 and $190 \mathrm{~nm}$; a discrepancy of -1 and $-1.2 \%$ was found, respectively. During the regular operations at Izaña, the SMPS is subject to weekly checks of aerosol and sheath airflows, zeroes and leak tests using absolute filters.

At Izaña, the aerosol instrumentation (SMPS and other devices) is located in a $6 \mathrm{~m}$-high building called PARTILAB (particles laboratory; Fig. 1b), where the indoor temperature is set to $20^{\circ} \mathrm{C}$. Temperature, relative humidity $(\mathrm{RH})$ and pressure are monitored in the aerosol flow (stretch of sampling pipe into the building, just before the aerosol monitors) and in the outdoor ambient air. Temperature and $\mathrm{RH}$ in the aerosol flow and in the outdoor ambient air are shown in Fig. 2. Outdoor ambient $\mathrm{RH}$ is usually low (70th percentile is $\sim 40 \%$ for hourly annual data). Because of the higher indoor temperature, the $\mathrm{RH}$ in the sample is usually much lower, within the range $10-25 \%$ (25th-75th percentiles for annual hourly data). Thus, dry aerosol measurements are performed without using any system for reducing RH (membrane/nafion driers, or dilutors).

The SMPS data availability is $74 \%$ for the study period (June 2008-June 2012). Non-valid data were flagged and not analysed. Correction for diffusion losses in the sampling pipe and inside the SMPS was applied (Hinds, 1999).
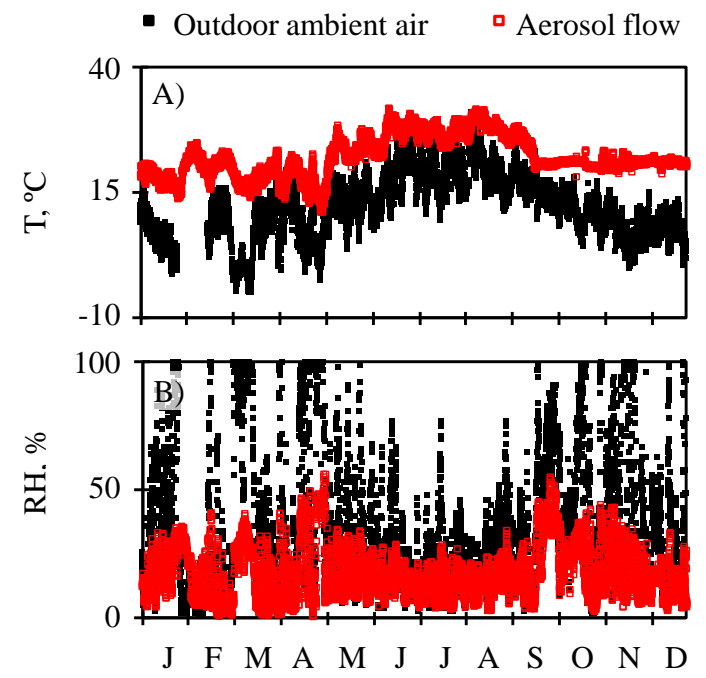

Fig. 2. Hourly mean values of temperature and relative humidity in the outdoor ambient air and in the aerosol flow of the SMPS during 2011 .

\subsubsection{Reactive gases and dust}

Reactive gases were measured using different principle of measurements: UV fluorescence analyser for $\mathrm{SO}_{2}$ (Thermo ${ }^{\mathrm{TM}}$, model 43C-TL), UV absorption for $\mathrm{O}_{3}$ (Thermo ${ }^{\mathrm{TM}}$, model $49 \mathrm{C}$ ) and chemiluminescence for $\mathrm{NO}$, $\mathrm{NO}_{2}$ and $\mathrm{NO}_{\mathrm{x}}\left(\right.$ Thermo ${ }^{\mathrm{TM}}$, model $\left.42 \mathrm{C}-\mathrm{TL}\right)$. In order to avoid the $\mathrm{NO}_{2}$ overestimation linked to the use of molybdenum converters, a photolytic $\mathrm{NO}_{2}$ to $\mathrm{NO}$ converter was used (Parrish and Fehsenfeld , 2000; Steinbacher et al., 2007). Quality assurance and quality control activities included (i) $15 \mathrm{~min}$ zero measurements, performed every $24 \mathrm{~h}$ in the $\mathrm{SO}_{2}$ and $\mathrm{O}_{3}$ and every $6 \mathrm{~h}$ in the $\mathrm{NO}_{\mathrm{x}}$ analysers; (ii) the use of linear fittings between consecutive zeros for applying zero correction to data; (iii) five-point span calibrations every 3 months with certified $\mathrm{SO}_{2}$ and $\mathrm{NO}_{\mathrm{x}}$ concentrations; and (iv) calibration of the $\mathrm{O}_{3}$ analyser versus an $\mathrm{O}_{3}$ primary standard (49C PS). A high linearity was commonly observed in these calibrations $\left(r^{2} \sim 0.999\right)$. Detection limit is $60 \mathrm{ppt}$ for $\mathrm{SO}_{2}, 50 \mathrm{ppt}$ for $\mathrm{NO}$ and $\mathrm{NO}_{\mathrm{x}}\left(5 \mathrm{~min}\right.$ average) and $1 \mathrm{ppb}$ for $\mathrm{O}_{3}$ ( 1 min average).

As Izaña is within the Saharan Air Layer in summer, the measurement programme includes (1) size distributions with the Aerodynamic Particle Sizer (APS, TSI ${ }^{\mathrm{TM}}$ ) for the range $0.7-20 \mu \mathrm{m}$ aerodynamic diameter $(\sim 0.7-12 \mu \mathrm{m}$ geometric diameter for dust) and (2) dust concentrations with the methods described by Rodríguez et al. (2011).

\subsubsection{Radiation}

The Izaña observatory has been part of the Baseline Surface Radiation Network (BSRN) since 2009 (García, 2011). We used short-wave downward radiation (SDR) irradiance (global, direct and diffuse), and UV-A and UV-B measurements. The global and diffuse SDRs were measured with 

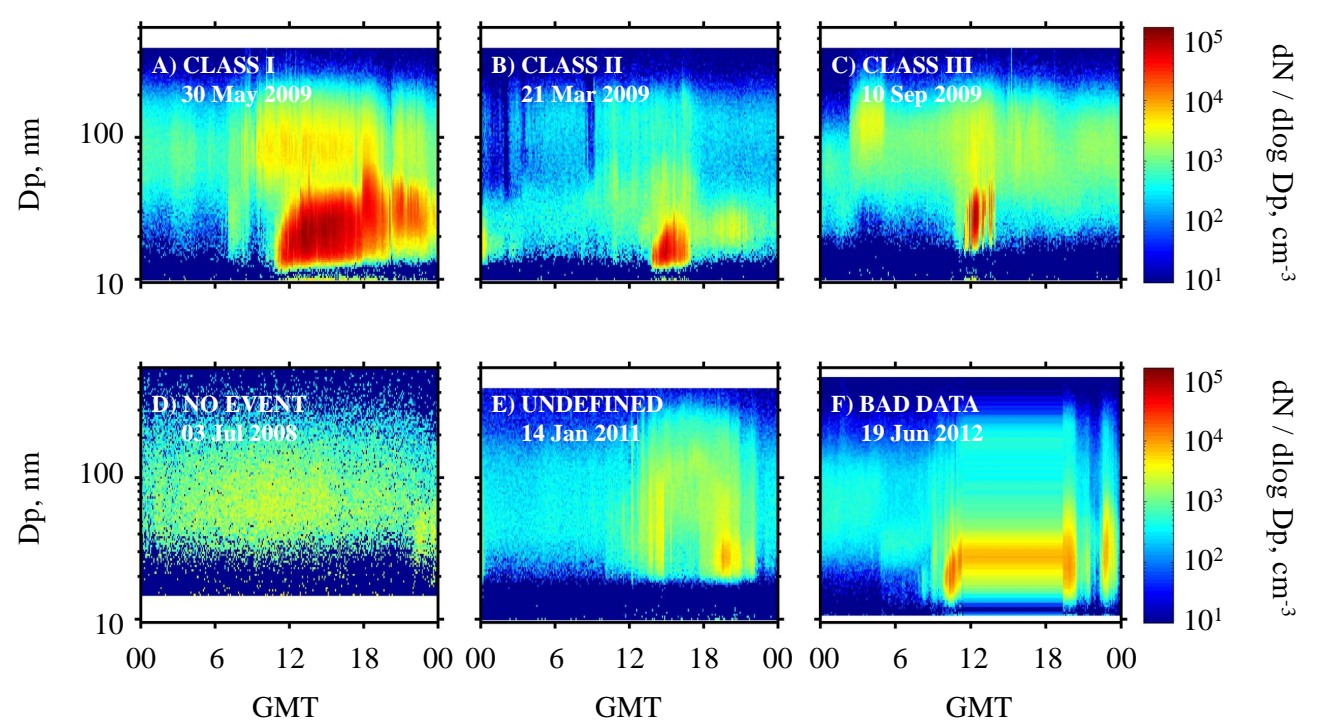

Fig. 3. Examples of type of events and cases identified in the data analysis.

unshaded and shaded Kipp \& Zonen CM-21 pyranometers, respectively. The spectral range covers $335-2200 \mathrm{~nm}(95 \%$ points), and the expected uncertainty is $\pm 2 \%$ for hourly totals. The direct SDR is measured with a Kipp \& Zonen $\mathrm{CH} 1$ pyrheliometer, with a field of view limited to $5^{\circ} \pm 0.2^{\circ}$, placed on a sun tracker with a tracking accuracy of $0.1^{\circ}$. The spectral range goes from 200 to $4000 \mathrm{~nm}$ (50\% points), and the uncertainty of this measurement is $\pm 2 \%$ for hourly totals. The UV-A is measured with Kipp \& Zonen UVS-A-T radiometer. The spectral range covers $315-400 \mathrm{~nm}$ with daily uncertainty lower than $5 \%$. The UV-B is measured with Yankee Environmental System (YES) UV-B-1 pyranometer. The spectral range goes from 280 to $320 \mathrm{~nm}$. All radiation parameters are measured with 1 min resolution.

\subsubsection{Meteorology}

Meteorological parameters were measured using a Setra 470 instrument for pressure, a Rotronic for temperature and relative humidity, and a Thies sonic anemometer for wind. Concentrations of water vapour were calculated with the Magnus equation. Vertical wind was only recorded from June 2011 to October 2011.

\subsection{Characterization of NPF events}

\subsubsection{Classification of events}

Daily aerosol number size distribution plots were visually analysed for identifying the "banana-type" NPF events (Dal Maso et al., 2005). Seven types of events were considered (Table 1 and Fig. 3). In events class I and II a clear particle formation and growth was observed for at least 4 and $2 \mathrm{~h}$, respectively. In class III events no particle growth was observed after the particle burst (apple-type events; Yli-Juuti et al., 2009). The remaining data were sorted as follows: nonevent (no increase in the concentration of particles $<25 \mathrm{~nm}$ was observed), undefined (event was not clearly observed) or bad data (invalid or missing data).

\subsubsection{Determination of formation (FR) and growth rate (GR)}

We attempted to determine the FR and GR for all class I events. However, this was not possible for a set of episodes in which a noisy signal was observed, mostly induced by a significant variability in the horizontal and/or vertical components of wind. Thus, events in which the FR and GR could be determined were sub-classified as class Ia; the remaining events were labelled as class Ib (Table 1).

The FR $\left(J_{\mathrm{D}}\right)$ and GR were calculated for the nucleation mode particles $(\mathrm{Dp}<25 \mathrm{~nm})$ using equations described by Kulmala et al. (2012):

$J_{\mathrm{D}}=\frac{\Delta N_{\mathrm{Dp}}, \mathrm{Dp}_{\max }}{\Delta t}+\mathrm{CoagS}_{\mathrm{Dp}} \cdot N_{\mathrm{Dp}}+\frac{\mathrm{GR}}{\Delta \mathrm{Dp}} \cdot N_{\mathrm{Dp}}+S_{\text {losses }}$,

where the first term is the slope obtained from the first-order polynomial fitting during the episode when representing the nucleation mode particle concentration as a function of time (Fig. 4). CoagS is the coagulation of particles in the size range $\left[D p, D p_{\max }\right] . \mathrm{Dp}_{\max }$ is the maximum size that the critical clusters may reach because of their growth during $\Delta t$ (GR). $S_{\text {losses }}$ takes into account additional losses, neglected in this study. Similarly,

$\mathrm{GR}=\frac{\mathrm{dDp}}{\mathrm{d} t}=\frac{\Delta \mathrm{Dp}_{\mathrm{m}}}{\Delta t}$,

where $D p_{m}$ belongs to the size range $\left[D p, D p_{\max }\right]$. GR is the slope obtained from the first-order polynomial fitting during 
Table 1. Type of events considered in this study. FR: formation rate. GR: growth rate.

\begin{tabular}{ll}
\hline Type & Criteria \\
\hline Class Ia (banana type) & $\begin{array}{l}\text { A new mode with growing mean diameter under } 25 \mathrm{~nm} \text { is observed. } \\
\text { The growth is observed during at least } 4 \mathrm{~h} \text {. FR and GR can be calculated. }\end{array}$ \\
Class Ib (banana type) & $\begin{array}{l}\text { A new mode with growing mean diameter under } 25 \mathrm{~nm} \text { is observed. } \\
\text { The growth is observed during at least } 4 \mathrm{~h} \text {, but FR and GR could not be calculated. }\end{array}$ \\
Class II (short banana type) & A new mode with growing mean diameter under $25 \mathrm{~nm}$ is observed. \\
& The growth period lasts from 2 to $4 \mathrm{~h}$. \\
Class III (apple/burst) & A new mode with growing mean diameter under $25 \mathrm{~nm}$ is observed. \\
& The growth period is lower than $2 \mathrm{~h}$. \\
Non-event & No new particle mode with mean diameter under $25 \mathrm{~nm}$ is observed. \\
Undefined & Event is not clearly observed. \\
Bad data & Missing or invalid data. \\
\hline
\end{tabular}
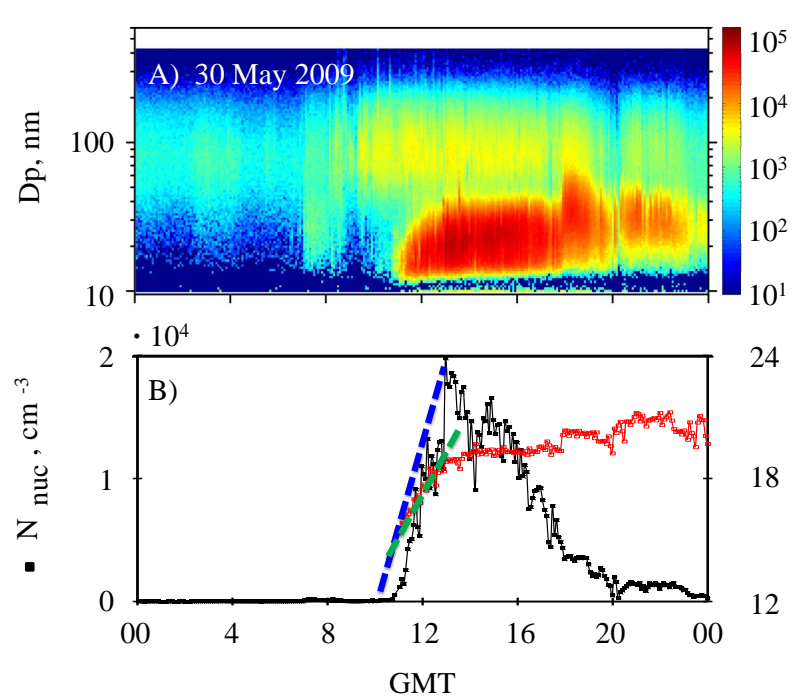

Fig. 4. Example of type Ia event. (A) Time evolution of the particle size distribution of the number of nucleation particles and $(\mathbf{B})$ of the geometric mean diameter for the nucleation mode. Lines illustrate the fitting that are performed for determining the formation and growth rates.

the episode when representing the nucleation mode geometric mean diameter as a function of time (Fig. 4). The FR and GR were determined using Eqs. (1) and (2) in two different approaches.

\section{Method 1: SMPS data}

The FR and GR were determined for the nucleation mode particles $(\mathrm{Dp}<25 \mathrm{~nm})$ using the number concentration ( $N_{\text {nuc }}$; Dal Maso et al., 2005) and the geometric mean diam-

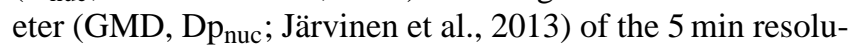
tion SMPS data. We used the GMD to avoid the human bias associated with other methods such as visual determination of the mode size change. Figure 4b shows an illustration of the linear fittings used for determining the slopes FR (Eq. 1) and GR (Eq. 2).

\section{Method 2: lognormal size distribution}

This method was implemented in two steps. First, each $5 \mathrm{~min}$ average size distribution was fitted to a linear combination of lognormal distributions:

$$
\begin{gathered}
\frac{\mathrm{d} N}{\mathrm{~d} \ln D p}=\Sigma_{(i=1)}^{n} \frac{N_{i}}{\sqrt{2 \pi \ln \sigma_{(g, i)}}} \\
\exp \left(-\frac{\left(\ln D p-\ln D_{p(g, i)}\right)^{2}}{2 \ln ^{2} \sigma_{(g, i)}}\right) .
\end{gathered}
$$

Each lognormal distribution is characterized by three parameters: mean number concentration $N_{i}$, geometric variance $\sigma_{(g, i)}^{2}$ and the geometric mean diameter $D_{p(g, i)}$. The fitting procedure was performed in a script programmed in Matlab $^{\text {TM }}$. The fitting accuracy was assessed by the least squares quadratic (LSQ) value between the measured particle number size distribution and its fitting. This method is usually applied considering a single nucleation mode $(<25 \mathrm{~nm})$, e.g. by Boy et al. (2008); Dal Maso et al. (2005); Salma et al. (2011); Yli-Juuti et al. (2009). However, we observed that, in many cases, the LSQ value was significantly reduced if the nucleation mode was fitted with 2 lognormal fittings instead of 1 . In many cases a simple visual analysis of the 5 min size distributions evidenced that the nucleation mode growth was prompted by one of these lognormal distribution. In the second step, GR was determined using Eq. (2).

\subsubsection{Determination of event parameters}

In order to quantify the contribution of $\mathrm{H}_{2} \mathrm{SO}_{4}$ to particle growth, we determined the following parameters: condensation sink (CS) and coagulation sink (CoagS) for each size 

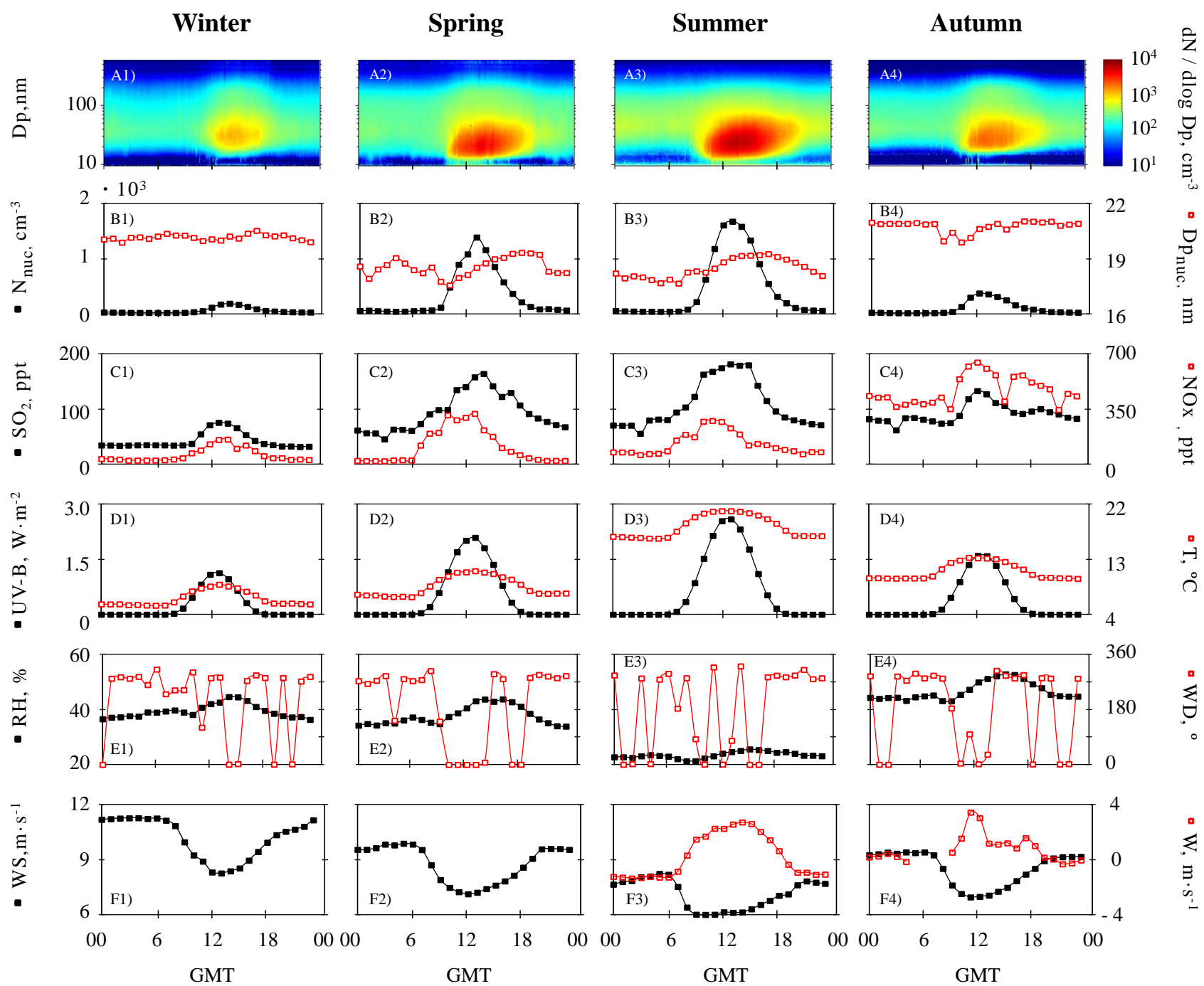

Fig. 5. Daily evolution (hourly mean values) per season of (A) aerosol particle number size distribution, (B) nucleation mode particle concentrations $\left(N_{\text {nuc }}\right)$ and the geometric mean diameter $\left(D p_{n u c}\right),(\mathbf{C}) \mathrm{SO}_{2}$ and $\mathrm{NO}_{\mathrm{x}},(\mathbf{D}) \mathrm{UV}-\mathrm{B}$ and temperature $(T)$, (E) relative humidity (RH) and wind direction (WD), and (F) horizontal wind (WS) and vertical (W) wind.

distribution (Kulmala et al., 2012); and concentration of condensable vapour $(\mathrm{Cv})$ and its source rate $(Q)$ (Dal Maso et al., 2005). For estimating concentrations of $\mathrm{H}_{2} \mathrm{SO}_{4}$ by the proxy of Petäjä et al. (2009), we used experimental data of $\mathrm{SO}_{2}$ and UV-B radiation at Izaña with Hyytiälä's parameters $\left(k=9.9 \times 10^{-7} \mathrm{~m}^{2} \mathrm{~W}^{-1} \mathrm{~s}^{-1}\right)$; the use of this value for $k$ instead of the actual (unknown) value at Izaña could have an influence on the absolute value of the $\mathrm{H}_{2} \mathrm{SO}_{4}$ concentration, but not the correlations. This proxy and the $\mathrm{Cv}$ equation were used to calculate the theoretical growth rate due to sulfuric acid $\left(\mathrm{GR}_{\mathrm{SA}}\right)$ (Nieminen et al., 2010).

\section{Results and discussion}

\subsection{Upward transport of particle precursors}

The daily evolution (hourly mean values throughout the day) of the particle size distribution, particle concentration and geometric mean diameter of the nucleation mode, $\mathrm{SO}_{2}, \mathrm{NO}_{\mathrm{x}}$, UV-B radiation and some meteorological parameters, averaged for each season is shown in Fig. 5. At Izaña, the number of particles exhibits strongly marked daily cycles, with much higher values during daytime than at night (Fig. 5b). This daytime increase is associated with a parallel increment in the $\mathrm{RH}$ and in the concentrations of $\mathrm{SO}_{2}, \mathrm{NO}_{\mathrm{x}}$ and $\mathrm{RH}$, which is prompted by the arrival of air from lower altitudes due to the development of orographic buoyant upward flows. The influence of these upward airflows on the concentrations 
Table 2. Total number and percentage of events observed from June 2008 to June 2012.

\begin{tabular}{lcr}
\hline Event type & Number of events & $\%$ \\
\hline Class Ia & 109 & 9.3 \\
Class Ib & 26 & 2.2 \\
Class II & 227 & 19.3 \\
Class III & 101 & 8.6 \\
Non-event & 514 & 43.6 \\
Undefined & 50 & 4.2 \\
Bad data & 151 & 12.8 \\
\hline Total days & 1178 & 100.0 \\
\hline
\end{tabular}

of precursors and nanoparticles $(<10 \mathrm{~nm})$ at Izaña was previously described in detail by Rodríguez et al. (2009). These upward airflows were also observed in other mountain observatories located on islands, such as Pico in Azores (Kleissl et al., 2007) and Mauna Loa in Hawaii (Weber et al., 1995, 1999). This ascent of air masses tends to occur during daytime linked to the heating of the terrain (Fig. 5F3 and F4). Previous studies at Mauna Loa and Izaña concluded that NPF is favoured in the boundary layer to the free troposphere transition region due to the low surface area of pre-existing particles (prompted by in-cloud particle scavenging), the high solar radiation conditions above the marine cloud layer and the gaseous precursor supply by the upward flows.

The high frequency of NPF events at Izaña results in a strongly marked daily cycle in the mean particle size distributions (Fig. 5a and b): after the increase in the number of particles $<25 \mathrm{~nm}$ (hereinafter so-called nucleation particles, $N_{\text {nuc }}$ ) typically observed between 10:30 and 13:30 GMT (depending on the season), a progressive increase in the geometric mean diameter is observed, in some cases even until the evening. These observations indicate that formation and growth of new particles $>10 \mathrm{~nm}$ tend to occur during the daytime upward flow period. This evidences that the nanoparticles $(<10 \mathrm{~nm})$ observed by Rodríguez et al. (2009) at Izaña frequently grow up to reach higher and stable diameters.

\subsection{Classification of episodes}

A total of 1178 days were classified in the study period (June 2008 to June 2012). The distribution of these events among the seven considered categories is shown in Table 2. Figure 6 shows the monthly distribution of episodes. Events in which a burst of nucleation particles $(<25 \mathrm{~nm})$ followed by particle growth (banana events) was observed during at least $2 \mathrm{~h}$ (type $\mathrm{Ia}+\mathrm{Ib}+\mathrm{II}$; examples in Fig. 3) accounted for $\sim 30 \%$ of the $4 \mathrm{yr}$ observations. Events with a duration longer than $4 \mathrm{~h}(\mathrm{I}=\mathrm{Ia}+\mathrm{Ib})$ accounted for $\sim 11 \%$ of the days. These banana events (I+ II) mostly occurred from May to October, when they accounted for more than $30 \%$ of the days of each month (Fig. 6a). The frequency of these
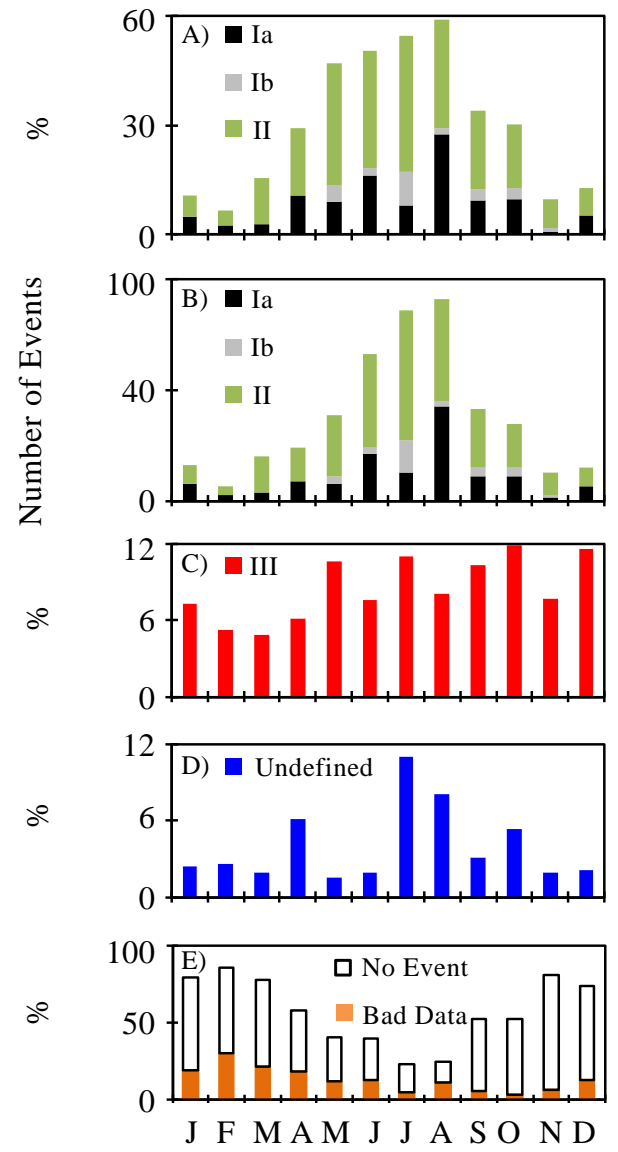

Fig. 6. (A, and $\mathbf{C}-\mathbf{E})$ Number of days per month (\%) in which each event (Ia, Ib, II, III, undefined, non-event and bad data) was observed. (B) Accumulated number of days (for the period 20082012) in which an event (Ia, Ib and II) was observed in each month.

events was at a maximum from June to August, when they accounted for $50-60 \%$ of the days per month (Fig. 6a). In each of these months, the accumulated number of events observed during the 4 study years was 50-75 (Fig. 6b). Events type III (burst of nucleation particles not followed by particle growth, also so-called apple-type events) occurred throughout the year, with a frequency within the range $5-12 \%$, without any significant seasonal behaviour (Fig. 6c). This indicates that although the formation of nucleation particles occurs throughout the different seasons (Fig. 6c), conditions for the particle growth mostly occur from May to October (Fig. 6a and b). Undefined events showed a higher frequency in July-August (Fig. 6d), whereas non-events mostly occurred from November to March (Fig. 6d).

The percentage of event days (I+II) we observed $(\sim 30 \%$; Table 2$)$ is somewhat lower than that observed at $3210 \mathrm{~m}$ a.s.l. on the summit of Mount Werner in North America ( 50\%; Hallar et al., 2011), at 5079 m a.s.l. in the Nepal Himalayas ( $43 \%$; Venzac et al., 2008) and in Puy de Dôme ( $38 \%$; Manninen et al., 2010), but higher than those observed at $2180 \mathrm{~m}$ a.s.l. in the Indian Himalayas $(\sim 11 \%$; 
Neitola et al., 2011) and at $3580 \mathrm{~m}$ a.s.l. in the Swiss Alps ( $\sim 20 \%$; Jungfraujoch; Boulon et al., 2010; Manninen et al., 2010).

At Izaña site, the NPF season occurs from May to August, when events (I+II) present a frequency of $\sim 50 \%$ (Fig. 6a). At Jungfraujoch these events occur from the end of spring to early autumn $(\sim 25 \%$ frequency during the season) as well, linked to the transport of precursors from the boundary layer (Boulon et al., 2010; Manninen et al., 2010). In the European continental boundary layer, these events are mostly observed in spring (Dal Maso et al., 2005; Hamed et al., 2007; Manninen et al., 2010), although in NW Italy they were mostly observed in autumn linked to specific north foëhn meteorological conditions (Rodríguez et al., 2005). In Puy de Dôme mount the maximum frequency of events was found during early spring and early autumn (Boulon et al., 2011). In the Nepal Himalayas these events were observed in the monsoon (July-September) and post-monsoon (October-December) seasons $(\sim 50 \%)$, whereas in the Indian Himalayas they occur in spring $(\sim 80 \%$ from March to June; Neitola et al., 2011). In the upper plateau of East Antarctica, Järvinen et al. (2013) reported that these events take place more often during summer.

\subsection{Formation and growth rates of new particles}

Figure 7 shows the monthly averages of the formation rates (FRs), growth rates (GRs) and other parameters during NPF events at Izaña from June 2008 to June 2012. As already described above, the FRs and GRs of the nucleation particles $(<25 \mathrm{~nm})$ could only be calculated for a set of events class I, which were labelled as class Ia. These determinations were performed for a total of 109 Ia events using the method 1 described in Sect. 2.3.2. At Izaña, NPF class Ia events (a) exhibit higher monthly averaged FR from April to September $\left(0.43-0.92 \mathrm{~cm}^{-3} \mathrm{~s}^{-1}\right)$ than from October to March $(0.19$ $0.27 \mathrm{~cm}^{-3} \mathrm{~s}^{-1}$; Fig. 7a), (b) show slightly higher GR from April to July $\left(0.48-0.58 \mathrm{~nm} \mathrm{~h}^{-1}\right)$ than from August to March $\left(0.26-0.44 \mathrm{~nm} \mathrm{~h}^{-1}\right.$; Fig. 7b), and (c) are longer from April to October $(6-7 \mathrm{~h})$ than from November to March $(5-6 \mathrm{~h}$; Fig. 7c). This shift in the duration is also associated with a shift in the starting and ending time of the events, clearly linked with the seasonal shift in the daytime length (Fig. 7d).

Mean values of FR and GR at Izaña were compared with those observed at other mountain sites (Table 3). Unfortunately, because of the lack of long-term studies, just mean values (and not seasonal behaviour) could be compared in most of the cases. GRs at Izaña and Mauna Loa are quite similar $\left(\sim 0.4 \mathrm{~nm} \mathrm{~h}^{-1}\right)$. These are significantly lower than those observed in mountains located in continental areas (2$12 \mathrm{~nm} \mathrm{~h}^{-1}$ ), where the higher regional emission of gaseous precursors and the enhanced vertical transport over the continental platform may account for the significantly higher GRs. FRs at Izaña and Mauna Loa are also similar; however, the low number of reported observations at mountain sites does
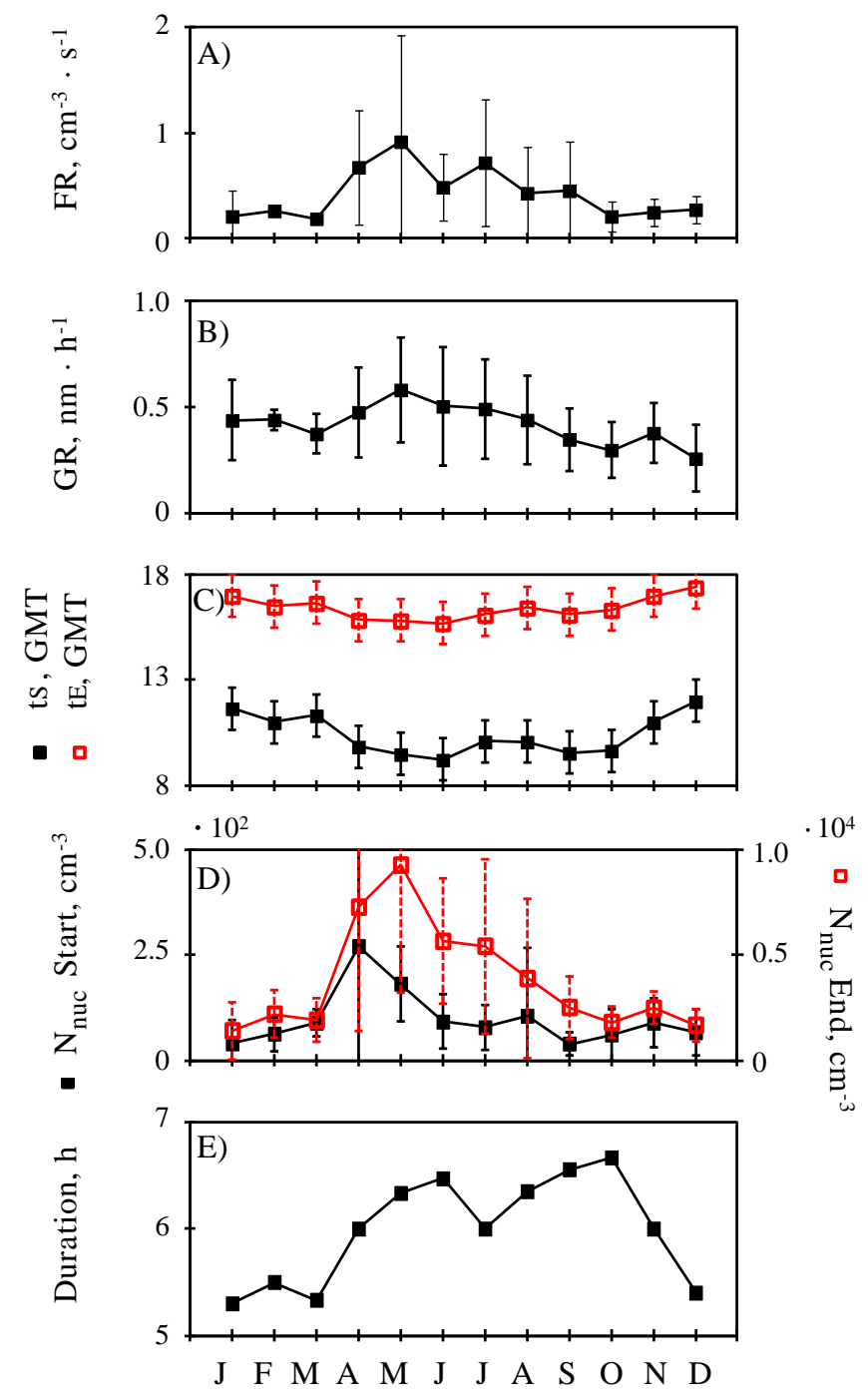

Fig. 7. Monthly mean \pm standard deviation values, during Ia episodes, of (A) formation rates (FRs), (B) growth rates (GRs), (C) start $\left(t_{\mathrm{S}}\right)$ and end $\left(t_{\mathrm{E}}\right)$ time of the events, (D) nucleation particle concentration at the start $\left(N_{\text {nuc }}\right.$ start $)$ and burst peak of the event ( $N_{\text {nuc }}$ end), and (E) duration of events.

not allow reaching any conclusion about differences between remote islands and continental areas. The amplitude of the seasonal variation of the FR at Izaña (min: $0.19 \mathrm{~cm}^{-3} \mathrm{~s}^{-1}$; max: $\left.0.92 \mathrm{~cm}^{-3} \mathrm{~s}^{-1}\right)$ is higher than that observed at Pyramid, Himalayas (min: $0.14 \mathrm{~cm}^{-3} \mathrm{~s}^{-1}$; max: $0.20 \mathrm{~cm}^{-3} \mathrm{~s}^{-1}$; Venzac et al., 2008), with max-FR to min-FR ratios equal to 4.7 at Izaña and 1.4 at Pyramid, Himalayas.

\subsection{Context during NPF events}

\subsubsection{Type Ia events}

In order to identify the parameters that influence, the NPF a set of analyses were performed. Mean values of the reactive 
Table 3. Values of formation rates and growth rates observed in this and in other studies at mountain sites. Footnotes indicate the references.

\begin{tabular}{|c|c|c|c|c|c|c|c|c|c|}
\hline $\begin{array}{l}\text { Mount/ } \\
\text { observatory }\end{array}$ & $\begin{array}{c}\mathrm{FR}, \\
\mathrm{cm}^{-3} \mathrm{~s}^{-1}\end{array}$ & Size range & $\begin{array}{c}\mathrm{GR}, \\
\mathrm{nm} \mathrm{h}^{-1}\end{array}$ & Size range & $\begin{array}{c}\mathrm{CS} \times 10^{-3} \\
\mathrm{~s}^{-1}\end{array}$ & $\begin{array}{c}\mathrm{Cv} \times 10^{7}, \\
\text { molecules } \mathrm{cm}^{-3}\end{array}$ & $\begin{array}{c}Q \times 10^{5} \\
\text { molecules } \mathrm{cm}^{-3} \mathrm{~s}^{-1}\end{array}$ & Region & $\begin{array}{c}\text { Altitude, } \\
\text { ma.s.l. }\end{array}$ \\
\hline Izaña & $0.46 \pm 0.57^{1}$ & $10-25 \mathrm{~nm}$ & $0.43 \pm 0.21^{1}$ & $10-25 \mathrm{~nm}$ & $1.55^{1}$ & $0.6^{1}$ & $0.095^{1}$ & Atlantic Ocean & 2400 \\
\hline Mauna Loa & $0.50 \pm \mathrm{N} / \mathrm{A}^{2 \mathrm{a}}$ & $3-10 \mathrm{~nm}$ & $0.40 \pm N / \mathrm{A}^{2 \mathrm{~b}}$ & $3-10 \mathrm{~nm}$ & & & & Pacific Ocean & 3400 \\
\hline Jungfraujoch & $0.90 \pm N / A^{3 a}$ & $2-3 \mathrm{~nm}$ & $6.00 \pm N / A^{3 a, 3 b}$ & $7-20 \mathrm{~nm}$ & $0.29^{3 b}$ & & $0.051^{3 b}$ & Europe & 3580 \\
\hline Puy de Dôme & $1.38 \pm 0.20^{4 a}$ & $2-3 \mathrm{~nm}$ & $6.20 \pm 0.12^{4 a}$ & $1.3-20 \mathrm{~nm}$ & $5.80^{4 b}$ & & & Europe & 1465 \\
\hline Pyramid & $0.18 \pm N / A^{5}$ & $10-20 \mathrm{~nm}$ & & & & & & Asia, Everest & 5079 \\
\hline Mukteshwar & $0.40 \pm N / A^{6}$ & $15-20 \mathrm{~nm}$ & $2.43 \pm N / A^{6}$ & $15-20 \mathrm{~nm}$ & $7.30^{6}$ & & & Asia, Himalaya & 2180 \\
\hline Norikura & & & $2.85 \pm \mathrm{N} / \mathrm{A}^{7}$ & $10-20 \mathrm{~nm}$ & $2.00^{7}$ & $2-3^{7}$ & $0.1-1^{7}$ & Asia, Japan & 2770 \\
\hline Mount Lemmon & & & $12.00 \pm \mathrm{N} / \mathrm{A}^{8}$ & $>16 \mathrm{~nm}$ & & $1-10^{8}$ & $1-10^{8}$ & North America & 2790 \\
\hline Rocky Mountains & & & $3.96 \pm N / A^{9}$ & $1-15 \mathrm{~nm}$ & $5.60^{9}$ & & & North America & 2900 \\
\hline Storm Peak & & & & & & & & & \\
\hline Laboratory & $7.47 \pm 5.1^{10}$ & $6-10 \mathrm{~nm}$ & $0.65 \pm 0.14^{10}$ & $>8 \mathrm{~nm}$ & $1.20^{10}$ & & & North America & 3210 \\
\hline Dome C & $0.023 \pm N / A^{11}$ & $10-25 \mathrm{~nm}$ & $2.50 \pm \mathrm{N} / \mathrm{A}^{11}$ & $10-25 \mathrm{~nm}$ & $0.18^{11}$ & $5.7^{11}$ & & Antarctica & 3200 \\
\hline
\end{tabular}

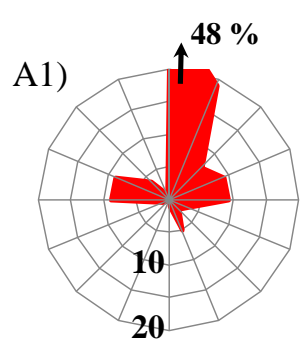

F Step, frequency $\%$
A2)

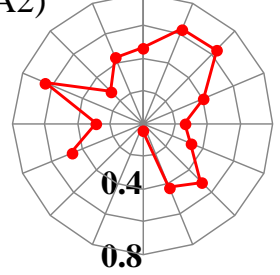

$\mathrm{FR}, \mathrm{cm}^{-3} \cdot \mathrm{s}^{-1}$
A3)

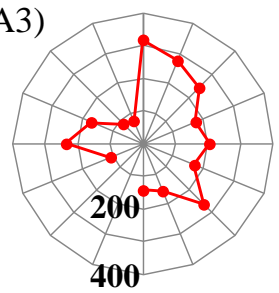

$\mathrm{SO}_{2}, \mathrm{ppt}$

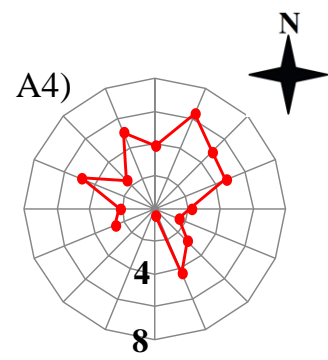

$\Delta \mathrm{N}_{\text {nuc }}, 10^{3} \cdot \mathrm{cm}^{-3}$

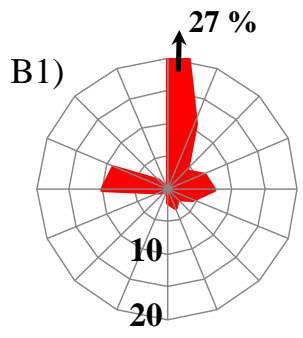

G Step , frequency \%
B2)

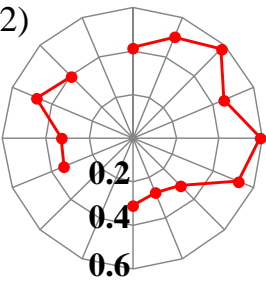

$\mathrm{GR}, \mathrm{nm} \cdot \mathrm{h}^{-1}$
B3)

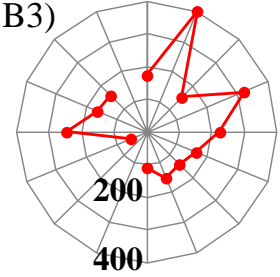

$\mathrm{SO}_{2}, \mathrm{ppt}$
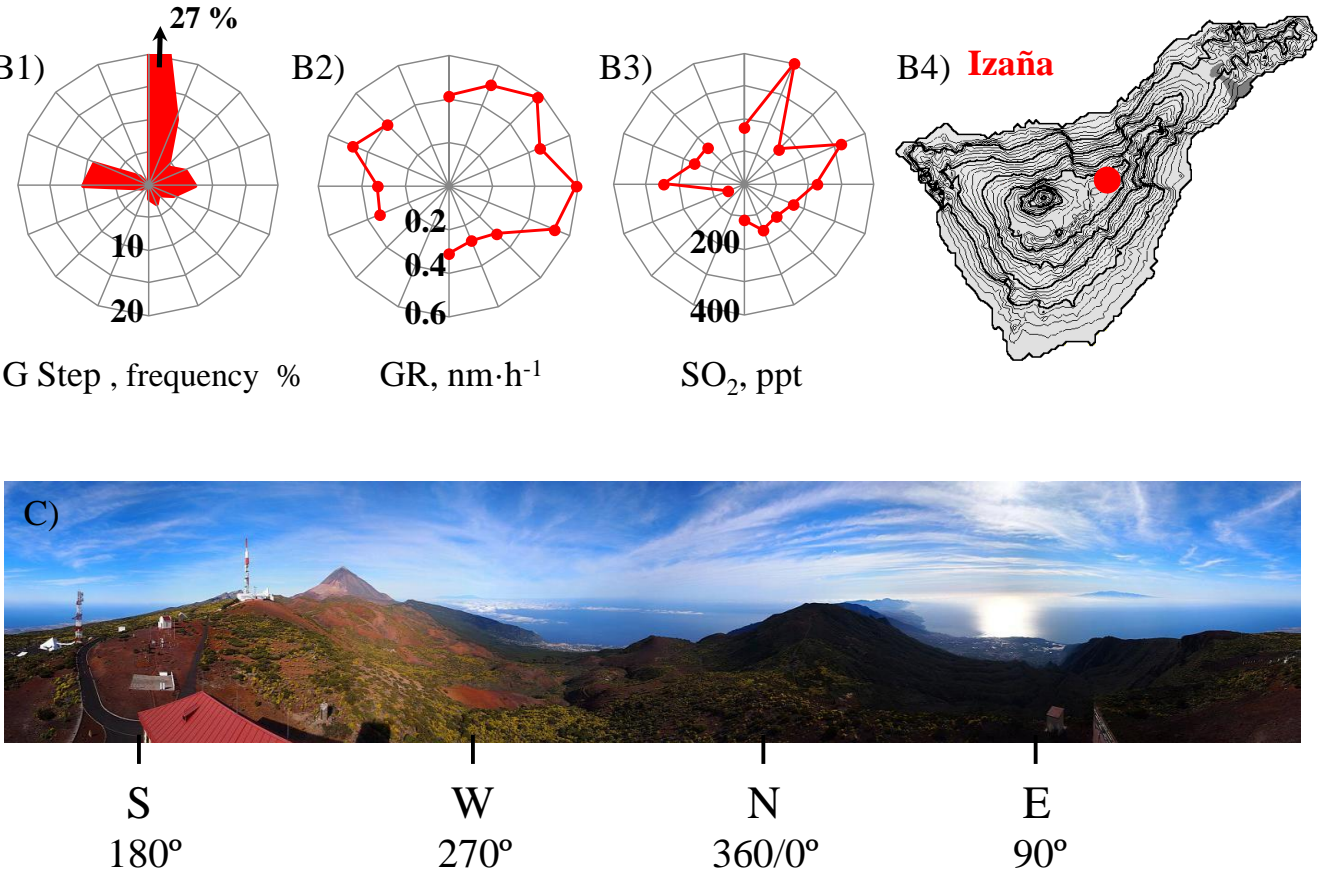

Fig. 8. Wind rose for formation step parameters ((A) frequency, formation rates, $\mathrm{SO}_{2}$ and nucleation particles concentration) and for growth step parameters $(\mathbf{B})$ frequency, growth rates and $\mathrm{SO}_{2}$ concentration). (B4) Topographic map of Tenerife. (C) $360^{\circ}$ view from Izaña observatory. 

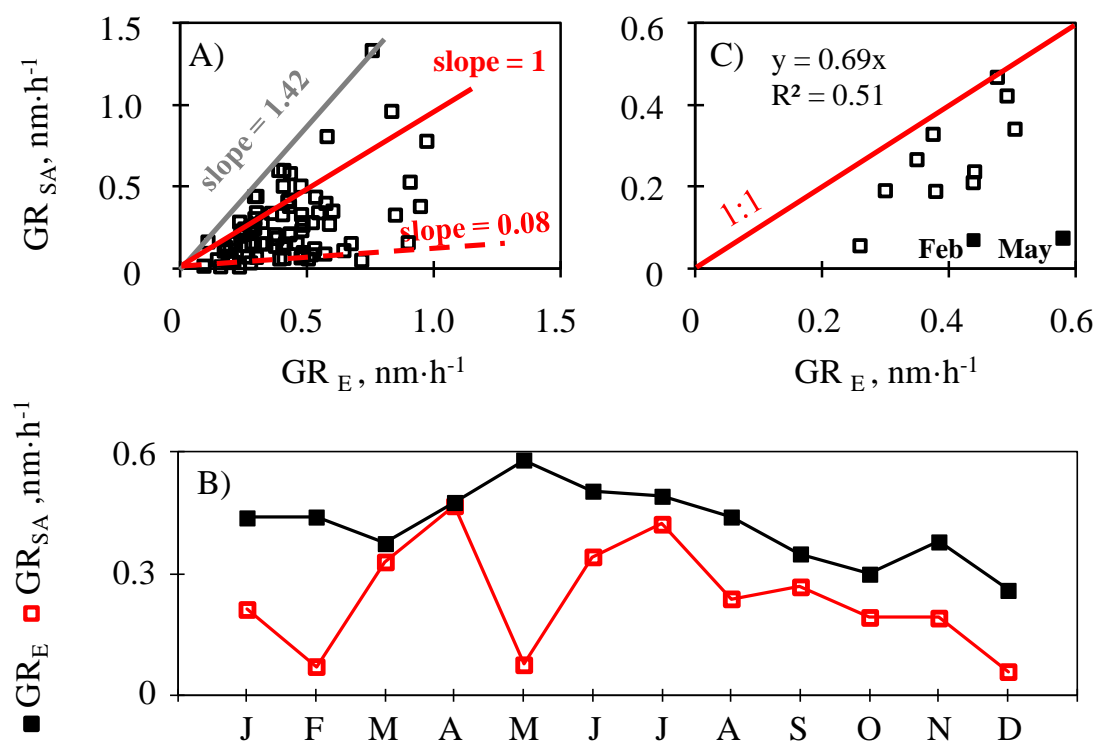

Fig. 9. (A) Growth rates of sulfuric acid $\left(\mathrm{GR}_{\mathrm{SA}}\right)$ versus experimental growth rates $\left(\mathrm{GR}_{\mathrm{E}}\right)$ in type Ia events. (B) Time series of monthly mean values of $\mathrm{GR}_{\mathrm{SA}}$ and $\mathrm{GR}_{\mathrm{E}}$. (C) Monthly mean values of $\mathrm{GR}_{\mathrm{SA}}$ versus $\mathrm{GR}_{\mathrm{E}}$ in type Ia events; fitting was performed excluding February and May.

Table 4. Mean values of a set of parameters in three different periods: (a) from 11:00-16:00 GMT for days with no particle formation (nonevents), (b) during the formation $(F)$ of the nucleation mode particles step in the NPF episodes, (c) during the particle growth $(G)$ step in the NPF episodes. Ratios of the mean " $F$ step to non-events" data, and of " $G$ step to non-events". Ratios $>1.2$ are highlighted in italic.

\begin{tabular}{lrrrrr}
\hline Parameter & $\begin{array}{r}\text { (a) Non-events, } \\
\text { mean }\end{array}$ & $\begin{array}{r}\text { (b) } F \text { step, } \\
\text { mean }\end{array}$ & $\begin{array}{r}\text { (c) } \begin{array}{r}\text { step, } \\
\text { mean }\end{array} \\
\text { ratio }\end{array}$ & $\begin{array}{r}F \text { step, } \\
\text { ratio }\end{array}$ \\
\hline Ozone $(\mathrm{ppb})$ & 43.3 & 42.3 & 42.9 & 1.0 & 1.0 \\
$\mathrm{SO}_{2}(\mathrm{ppt})$ & 83.2 & 238.3 & 233.7 & 2.9 & 2.8 \\
$\mathrm{NO}_{\mathrm{X}}(\mathrm{ppt})$ & 317.9 & 204.0 & 196.7 & 0.6 & 0.6 \\
$\mathrm{Global}\left(\mathrm{W} \mathrm{m}^{-2}\right)$ & 719.2 & 881.5 & 833.1 & 1.2 & 1.2 \\
Diffuse $\left(\mathrm{W} \mathrm{m}^{-2}\right)$ & 796.1 & 940.4 & 884.0 & 1.2 & 1.1 \\
Direct $\left(\mathrm{W} \mathrm{m}^{-2}\right)$ & 160.2 & 128.4 & 129.5 & 0.8 & 0.8 \\
UV-B $\left(\mathrm{W} \mathrm{m}^{-2}\right)$ & 1.2 & 1.7 & 1.6 & 1.4 & 1.3 \\
UV-A $\left(\mathrm{W} \mathrm{m}^{-2}\right)$ & 46.2 & 56.3 & 53.4 & 1.2 & 1.2 \\
$T\left({ }^{\circ} \mathrm{C}\right)$ & 10.9 & 18.4 & 18.1 & 1.7 & 1.7 \\
Relative humidity $(\%)$ & 44.8 & 29.2 & 32.0 & 0.7 & 0.7 \\
Water vapour $\left(\mathrm{g} \mathrm{cm}^{-3}\right)$ & 3.2 & 2.8 & 3.1 & 0.9 & 1.0 \\
Wind speed $\left(\mathrm{m} \mathrm{s}^{-1}\right)$ & 8.9 & 4.6 & 4.7 & 0.5 & 0.5 \\
Wind $X$ component $\left(\mathrm{m} \mathrm{s}^{-1}\right)$ & 2.6 & 0.8 & 1.1 & 0.3 & 0.4 \\
Wind $Y$ component $\left(\mathrm{m} \mathrm{s}^{-1}\right)$ & -4.2 & 0.0 & -0.4 & 0.0 & 0.1 \\
Vertical wind $\left(\mathrm{m} \mathrm{s}^{-1}\right)$ & 0.8 & 2.7 & 3.2 & 3.5 & 4.3 \\
\hline
\end{tabular}

gases $\left(\mathrm{SO}_{2}, \mathrm{NO}_{\mathrm{x}}\right.$ and $\left.\mathrm{O}_{3}\right)$, dust concentrations, radiation components (global, diffuse, direct, UV-A and UV-B) and meteorological parameters ( $T$, RH, water vapour, wind vector components, speed and direction) were determined during the two steps of each NPF episode: (1) step 1 - formation of the nucleation particles and (2) step 2 - subsequent particle growth. These determinations were performed for the 109 events of type Ia. The resulting database was then subjected to different analysis (Tables 4 and 5; Figs. 8-12).
Table 4 shows the ratios of the mean value of each parameter during the formation $(F)$ and growth $(G)$ steps to the average value at Izaña for non-event days from 11:00 to 16:00 GMT. The same parameters show high ratios $(>1.2)$ during the formation and during the growth steps: sulfur dioxide (2.9-2.8), vertical wind component (3.5-4.3) and UV-B (1.4-1.3) radiation. This supports the idea that upward transport of sulfur dioxide (from the boundary layer) and its 

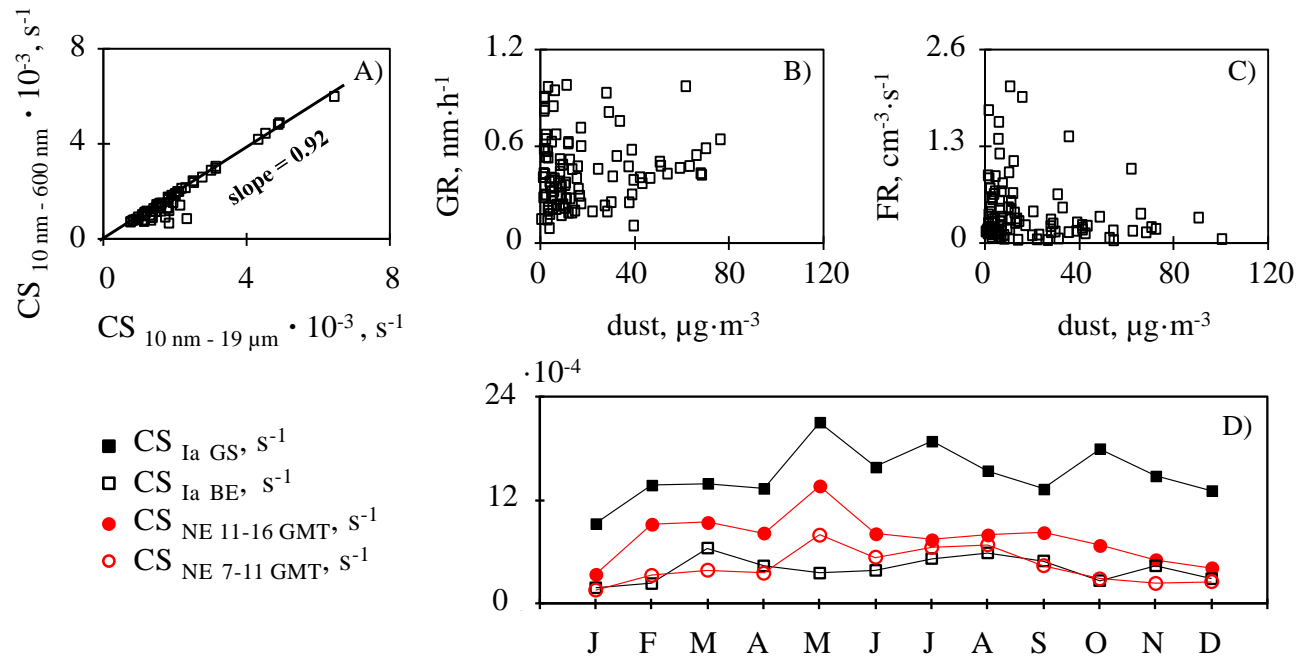

Fig. 10. (A) $\mathrm{CS}_{10-600 \mathrm{~nm}}$ versus $\mathrm{CS}_{10 \mathrm{~nm}-19 \mu \mathrm{m}}$, (B-C) Scatter plots of the formation rates (FR) and growth rates (GR) versus dust concentration at Izaña during the NPF events (type Ia), (D) comparative analysis of the CS during NPF events and during non-events. Monthly means of CS during two stages of the NPF event: (i) at the start of the NPF and (ii) during the growth step. Similarly, it is shown at two periods during non-events: (i) 07:00-11:00 GMT ( start time during NPF) and (ii) 11:00-16:00 GMT ( typical time of the growth step during NPF).

further photo-oxidation by UV radiation is a key process in the NPF.

Mean values of the study parameters during the formation and growth steps were plotted against wind direction (Fig. 8). Most of the formation step and growth step in the events occur under northern $(\mathrm{N}-\mathrm{NNE})$ wind conditions $(\sim 50 \%$ for the $F$ and $27 \%$ for $G$ steps, respectively) and secondarily under eastern (ENE-E) and western (WNW-W) winds $(\sim 10 \%$ for both directions; Fig. 8A2 and B2).

The highest FRs and GRs are observed when air blows from the eastern side $\left(0-180^{\circ}\right)$, which is the sector associated with the highest $\mathrm{SO}_{2}$ concentrations (Fig. 8A3 and B3). This precursor also influences the number of nucleation particles formed during the formation step $\left(\Delta N_{\text {nuc }}\right)$; the highest concentrations are recorded during NE winds (Fig. 8A4).

Different studies in mountain sites show the same behaviour for $\mathrm{SO}_{2}$ (Boy et al., 2008), radiation (Boulon et al., 2010; Salma et al., 2011; Venzac et al., 2008), $\mathrm{O}_{3}$ (Hallar et al., 2011) and relative humidity (Boy et al., 2008) when evaluating event and non-event days. In the boundary layer, in the Po Valley (northern Italy), Hamed et al. (2007) observed that temperature, wind speed, solar radiation, $\mathrm{SO}_{2}$ and $\mathrm{O}_{3}$ concentrations were on average higher on nucleation days than on non-event days, whereas relative humidity and $\mathrm{NO}_{2}$ concentration were lower. These conditions are similar to those we observed at Izaña, except for wind speed and ozone (Table 4). At Izaña, a moderate correlation between the concentration of nucleation particles with ozone was observed only in spring, when biogenic emissions tend to increase. Oxidation products of biogenic volatile organic com- pounds could also take part in the growth processes (Held et al., 2004; Yli-Juuti et al., 2011).

\subsubsection{Contribution of sulfuric acid to particle growth}

The contribution of sulfuric acid to particle growth was estimated for Ia events using the theoretical equations described above. The GR resulting from this sulfuric acid concentration $\left(G_{S A}\right)$ is plotted versus the experimental GR $\left(G_{E}\right)$ in Fig. 9a. The whole data set is comprised between two welldefined lines with slopes 0.08 and 1.42 . These results show that the sulfuric acid condensation accounts for 8-100\% of the observed GR, depending on the event (Fig. 9a). Time series of monthly mean values of $\mathrm{GR}_{\mathrm{E}}$ and $\mathrm{GR}_{\mathrm{SA}}$ are plotted in Fig. 9b. Growth rates of sulfuric acid account for most of the observed growth rates during most of the time. Observe in Fig. 9c how monthly mean values of $\mathrm{GR}_{\mathrm{E}}$ and $\mathrm{GR}_{\mathrm{SA}}$ tend to show a high correlation throughout the year. As average, GR $_{\mathrm{SA}}$ accounted for $69 \%$ of $\mathrm{GR}_{\mathrm{E}}$ (Fig. 9c), excluding Febru-

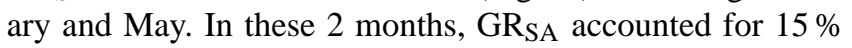
of $\mathrm{GR}_{\mathrm{E}}$ as average. An interesting behaviour is observed in May, when the highest $\mathrm{GR}_{\mathrm{E}}\left(\sim 0.6 \mathrm{~nm} \mathrm{~h}^{-1}\right)$ and the lowest contribution of sulfuric acid $(13 \%)$ to particle growth were observed (Fig. 9b and c). This strongly suggests a significant involvement of other condensing vapours in this period. Similar conclusions were reached after analysing the particle growth rates in Dome $\mathrm{C}$ mount in Antarctica (Järvinen et al., 2013) and in Fichtelgebirge mountains in Germany (Held et al., 2004). A number of studies have shown that oxidation products of monoterpenes may contribute to particle growth (e.g. Held et al., 2004). In Tenerife, these emissions occur in the forest pine that is present between 500 and 

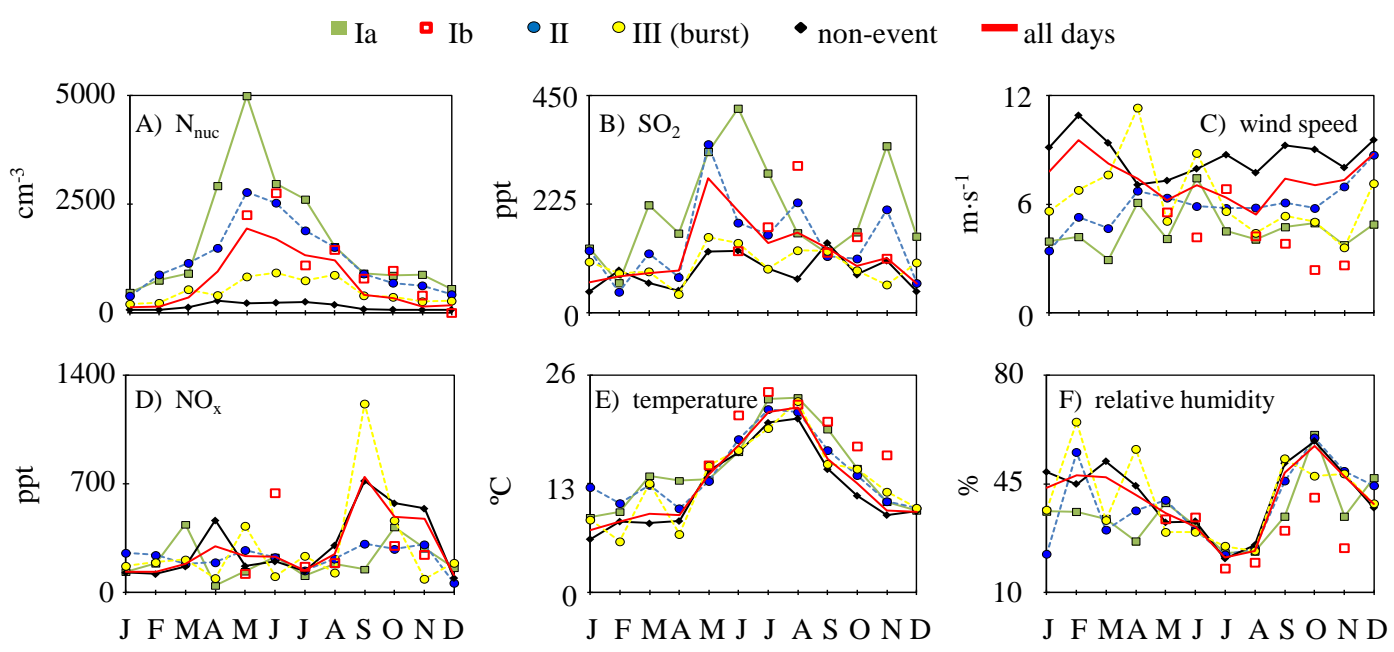

Fig. 11. Monthly mean values (calculated with hourly mean values from 11:00 to 16:00 GMT) of a set of parameters during days in which episodes type Ia, Ib, II, III and non-event were registered. Mean values with all days of the months are also included.

$2000 \mathrm{~m}$ a.s.l. around the island and that affects Izaña during the upward flow diurnal periods.

The variability of the GR depends on the balance between the rate at which condensable vapours are supplied from their source $(Q)$ and the rate at which these vapours condense onto pre-existing particles (CS). The larger the degree of CS, the faster new formed nuclei must grow to survive scavenging onto larger pre-existing particles (Kulmala et al., 2004). At Izaña it seems that there is high vapour source rate and low enough CS to allow rather slowly growing nucleation mode to survive to larger sizes (Table 3).

We analysed two specific issues concerning the CS. First, we quantified how the presence of Saharan dust influences the CS. Figure 10a shows the CS calculated for the size range 10-600 nm (SMPS data) versus the CS for the size range $10 \mathrm{~nm}-12 \mu \mathrm{m}$ (SMPS + APS data). The contribution of the particles with a geometric diameter $0.7-12 \mu \mathrm{m}$ (APS range) to the CS is relatively low $(\sim 8 \%)$. Because of this, the GR vs. CS scatter plot (not shown for the sake of brevity) did not change significantly when the CS included the APS data. This result is consistent with the poor correlation observed between GR and dust concentrations discussed above (Fig. 10b). In contrast, FR shows a significant negative correlation with dust (Fig. 10c). This suggests that Saharan dust may play an important role in scavenging freshly formed nucleation particles. This mechanism could contribute to the observed coating of dust by sulfate in Saharan dust particles emitted in desert regions affected by $\mathrm{SO}_{2}$ emissions (Rodríguez et al., 2011).

Second, in order to assess how the condensation of vapours onto pre-existing particles influences NPF, we compared the evolution of CS during NPF events with that during nonevents (Fig. 10d). In NPF events, CS at the beginning of the episode is lower than during the growth step. Moreover, CS is higher during NPF than during non-events in the same period (11:00-16:00 GMT). These results are similar to those observed in other mountain sites such as Jungfraujoch (Boulon et al., 2010) and the Rocky Mountains (Boy et al., 2008). An opposite behaviour has been observed in the continental boundary layer, where condensation onto pre-existing particles and nucleation are competing processes that influence the day-to-day variability in the NPF events (Rodríguez et al., 2005; Hamed et al., 2007). This is not observed in mountain sites due to the low backgrounds of aerosols and vapours.

\subsubsection{Type Ia versus other type events}

The context in which type Ia events occur was compared with that in which the other events (Table 1) occur. For this, the monthly mean value (from 11:00 to 16:00 GMT) of a set of parameters during the different types of events (Ia, $\mathrm{Ib}$, II, III and non-event) was compared with the monthly mean value (from 11:00 to 16:00 GMT) for these parameters (Fig. 11). Some features that differentiate the events are as follows: (a) the highest concentrations of nucleation particles were observed during NPF events (Ia, Ib and II), when $N_{\text {nuc }}$ concentrations are 2-3 times higher than during burst (III) episodes (Fig. 11a), and (b) length of the NPF events seems to be conditioned by $\mathrm{SO}_{2}$ availability, which in turn is influenced by wind. Observe how $\mathrm{SO}_{2}$ concentrations during events type I (which last at least $4 \mathrm{~h}$ ) are higher than during events II (which last 2-4h) and burst episodes (III; Fig. 11b) and how wind speed decreases throughout the sequence of episodes non-event, burst (III) and banana types II and I (Fig. 11c) - a trend opposite to that of $\mathrm{SO}_{2}$ (Fig. 11b).

Other features commonly reported for NPF events are also observed at Izaña: (c) except for a few cases, concentrations of $\mathrm{NO}_{\mathrm{x}}$ tend to be lower during type I banana events 


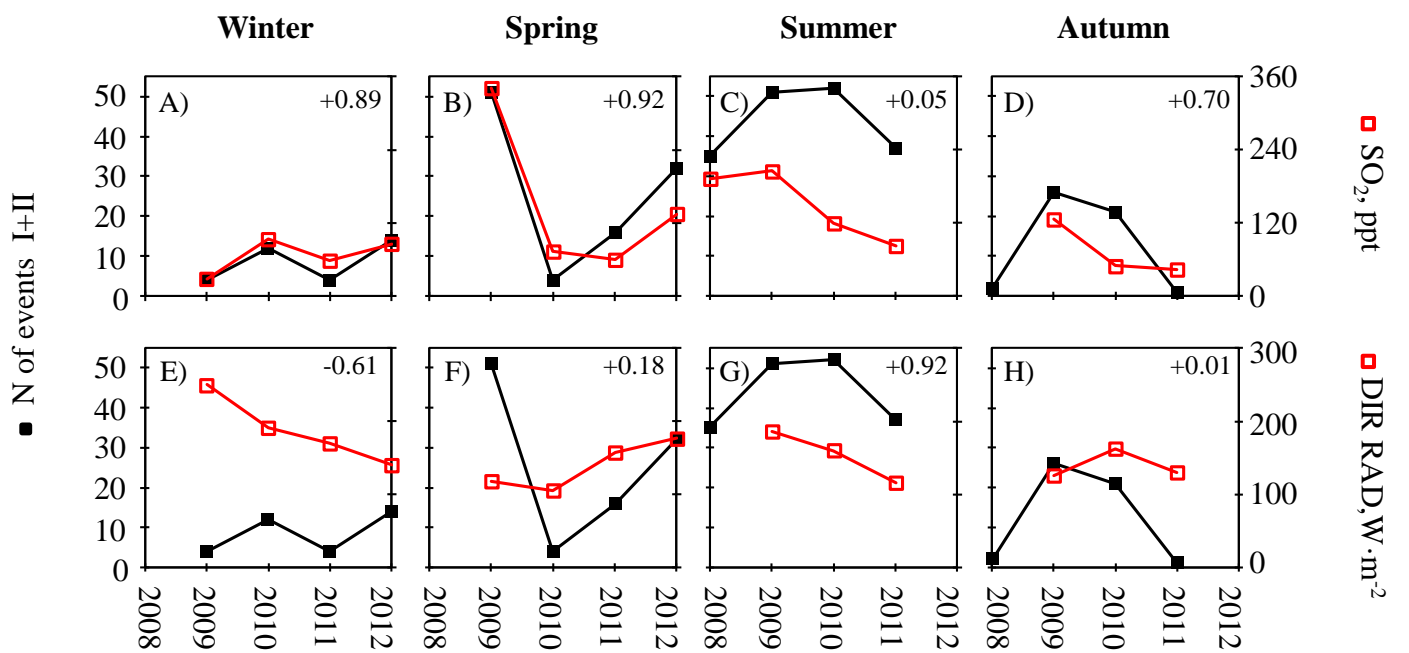

Fig. 12. Number of banana-type events (I+ II) and mean values (11:00-16:00 GMT) of $\mathrm{SO}_{2}$ and direct radiation per season for the period June 2008-June 2012 at Izaña: winter (Jan-Mar), spring (Apr-Jun), summer (Jul-Sep) and autumn (Oct-Dec).

(Fig. 11d; Boy and Kulmala, 2002; Hamed et al., 2007). (d) Temperature is higher and relative humidity is lower during events type I $(\mathrm{Ia}+\mathrm{Ib})$ than monthly mean values and lower than during burst (III) and non-event episodes (Fig. 11e and f; Rodríguez et al., 2005; Hamed et al., 2007). (e) Global, UV-A and UV-B radiation during events type I (banana $>4 \mathrm{~h}$ ) tend to be higher than during the other event types (II, III and non-event; Birmili and Wiedensohler, 2000; Boy and Kulmala, 2002; Hamed et al., 2007; Manninen et al., 2010).

\subsection{Year-to-year variability}

Processes that influence the year-to-year variability of the frequency of each type of episode (Table 1) were studied. For this purpose, the frequency of each type of event was correlated with the reactive gases, condensation sink, sulfuric acid proxy, radiation and meteorological parameters for each season from June 2008 to June 2012. Here we focus just on the key issues for the sake of brevity.

The year-to-year variability in the the frequency of NPF events (I+ II) for each season, for the period 2008-2012, showed the highest correlation with $\mathrm{SO}_{2}$. The correlation was higher from autumn to spring ( $r: 0.70-0.92)$ than in summer $(r: 0.05$; Fig. 12a-d). This indicates that other processes apart from transport of precursors influence NPF in summertime. In this season, the number of banana-type events (I + II) exhibited a significant correlation with direct radiation (Fig. 12g), and an evident negative correlation with diffuse radiation (not shown in plots). Because diffuse radiation is dominated by Saharan dust at Izaña (García et al., 2014), direct radiation is indicative of clean (dust free) conditions. This indicates that the presence of dust may influence the year-to-year variability in the NPF frequency. This may occur by two processes: first, reducing the amount of radiation reaching the surface (negative forcing) and, second, acting as a sink of freshly formed nucleation particles and vapours. The number of banana-type NPF events (I + II) also exhibited a significant correlation with UV-B radiation during autumn and winter $(r:+0.9)$, when they showed their lowest seasonal levels $\left(\sim 1 \mathrm{~W} \mathrm{~m}^{-2}\right.$; not shown in plots). This suggests that UV-B radiation (which drives photochemical reactions, leading to oxidation of $\mathrm{SO}_{2}$ ) may be an important influencing parameter in autumn-winter, but not in summer because of the persistently high day-to-day levels $\left(\sim 2 \mathrm{~W} \mathrm{~m}^{-2}\right)$.

\subsection{Some considerations about the nucleation mode}

The determination of the formation and growth rates is usually performed assuming that the size distribution in the nucleation range $(<25 \mathrm{~nm})$ is constituted by a single mode (Boy et al., 2008; Dal Maso et al., 2005; Salma et al., 2011; Yli-Juuti et al., 2009). In many of the type Ia events we analysed, this hypothesis is supported. However, we detected a significant number of events type Ia in which two nucleation modes were clearly observed. Moreover, the evolution and growth rates of these two modes were in many cases markedly different. Observe in the example shown in Fig. 13 how the nucleation mode 2 (orange arrow) experiences a faster development than the nucleation mode 1 (green arrow).

In a selection of four type Ia events, the growth rates were calculated with three different techniques: (i) directly with the SMPS data (as for data of Figs. 7-8), (ii) after performing a fitting to 3 lognormal distributions (1 nucleation, 1 Aitken and 1 accumulation mode), and (iii) after performing a fitting to 4 lognormal distributions ( 2 nucleation, 1 Aitken and 1 accumulation mode). GRs obtained from the "1 lognormal mode nucleation fitting" are higher than those obtained directly from the SMPS data (Table 5). Differences in the GR when comparing different techniques were also described by Yli-Juuti et al. (2009). When considering the two nucleation 

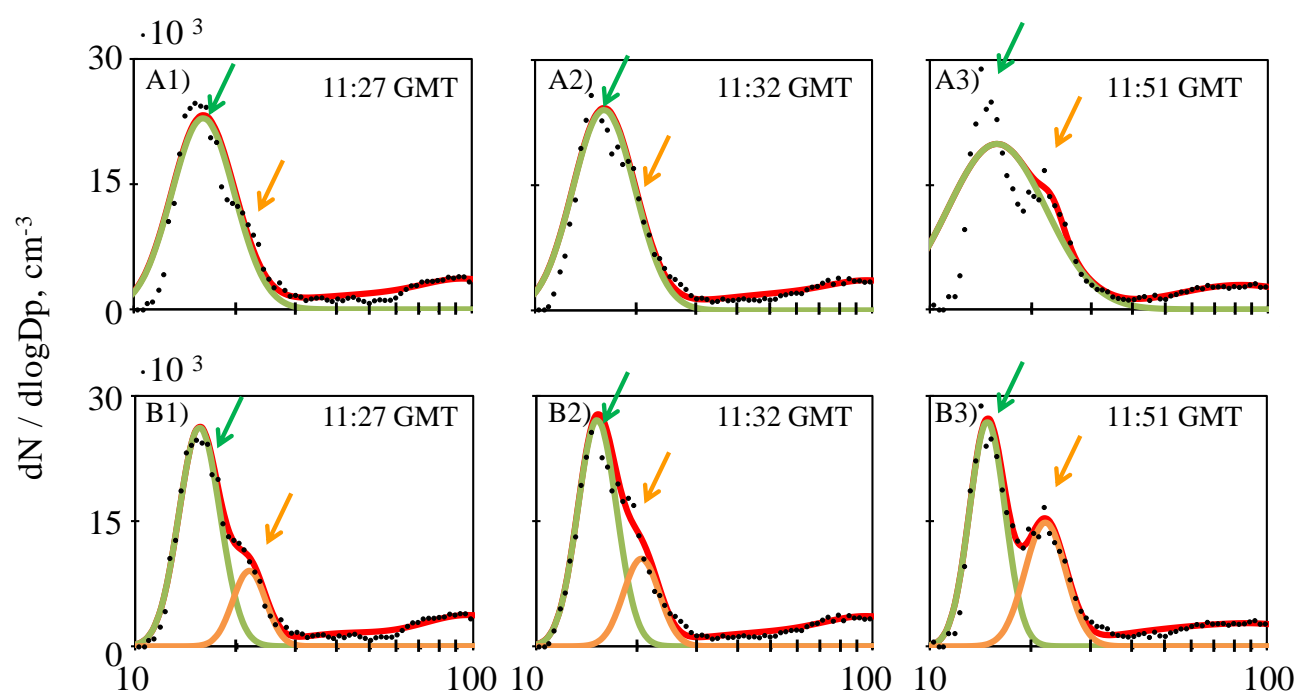

$\mathrm{Dp}, \mathrm{nm}$

Fig. 13. Example of a banana-type Ia event (30 May 2009) in which two nucleation modes were observed (highlighted with green and orange arrows). (A) Fitting to 2 lognormal distributions with one nucleation mode (green line). (B) Fitting to 3 lognormal distributions with two nucleation modes (green and orange lines). Black dots represent measured data; red line represents the sum of all the fitted modes.

Table 5. Mean values of growth rates during four type Ia determined with three methods: (1) SMPS data, (2) fitting to 3 lognormal mode with 1 nucleation mode, and (3) fitting to 4 lognormal mode with 2 nucleation mode.

\begin{tabular}{lcccc}
\hline & $\mathrm{GR}, \mathrm{nm} \mathrm{h}^{-1}$ & $\mathrm{GR}, \mathrm{nm} \mathrm{h}^{-1}$ & $\mathrm{GR}, \mathrm{nm} \mathrm{h}^{-1}$ & $\mathrm{GR}, \mathrm{nm} \mathrm{h}^{-1}$ \\
\hline & \multicolumn{4}{c}{ Method } \\
\cline { 2 - 5 } Day & SMPS data & $\begin{array}{c}\text { 1 nuc. } \\
\text { mode fitting }\end{array}$ & $\begin{array}{c}\text { 2 nuc. mode fitting } \\
\text { (nuc. mode 1) }\end{array}$ & $\begin{array}{c}\text { 2 nuc. mode fitting } \\
\text { (nuc. mode 2) }\end{array}$ \\
\hline 30 May 2009 & 0.98 & 1.40 & 0.27 & 0.58 \\
5 Jul 2009 & 0.46 & 1.74 & 1.01 & 0.55 \\
16 Aug 2010 & 0.39 & 1.40 & 0.83 & 0.56 \\
20 Aug 2010 & 0.90 & 3.44 & 0.59 & 1.59 \\
\hline
\end{tabular}

mode fittings, in some cases the GR of mode 1 is higher than that of mode 2, and the opposite. This illustrates how the two nucleation modes may have markedly different evolution. The second nucleation mode was present in $47 \%$ of 55 events observed from April 2009 to August 2010. A more detailed analysis is needed to describe the context in which these episodes take place.

\section{Summary and conclusions}

We studied new particle formation (NPF) at high altitude in the subtropical North Atlantic, at the Izaña Global Atmosphere Watch observatory (2373 m a.s.1.; Tenerife, Canary Islands). NPF is associated with the transport of gaseous precursors from the boundary layer by orographic buoyant upward flows that perturb the low free troposphere during daytime. In the 4-year study period, NPF events took place during $30 \%$ of the days with a clearly marked NPF season (May-August), where monthly mean values of the formation and growth rates exhibited high values, $0.49-0.92 \mathrm{~cm}^{-3} \mathrm{~s}^{-1}$ and $0.48-0.58 \mathrm{~nm} \mathrm{~h}^{-1}$, respectively. At Izaña, growth rates are significantly lower than those observed in mountain sites located in continental areas. Formation and growth rates are similar to those reported for remote mountains located in oceanic areas (e.g. Mauna Loa, Hawaii). The results of our analysis show that sulfur dioxide accounts for most of the observed particle growth during most of the year $(\sim 70 \%)$, except for February and May when other vapours seem to contribute to the particle growth as well. The availability of $\mathrm{SO}_{2}$ (typical concentrations within the range 60-300 ppt) seems also to be the most influencing parameter in the year-to-year variability in the frequency of NPF events. 
Summertime observations, when Izaña is within the Saharan Air Layer, suggest that dust particles may play a significant role acting as coagulation sink of freshly formed nucleation particles. As a novel finding, a set of NPF events in which two nucleation modes may evolve at different rates was identified. Further studies are needed to investigate aerosol dynamical processes involving two nucleation modes.

Acknowledgements. For this study the author has received two grants: first, "in-situ aerosol studies" from AEMET and, subsequently, a pre-doctoral fellowship within the training program for research staff of the Canarian Agency for Research, Innovation and Information Society (ACIISI) of the Government of the Canary Islands, co-financed by the European Social Fund. This study was performed within the context of several projects, supported by the Ministry of Economy and Competitiveness of Spain (POLLINDUST, CGL2011-26259), REDMAAS (CGL201115008-E) and GRACCIE (CSD2007-00067) and by the European Union (FP7, ACTRIS, grant contract: 262254). Measurements at Izaña observatory are performed within the context of the Global Atmosphere Watch networks with the financial support of AEMET. The excellent work performed by Conchy Bayo, Cándida Hernández, Fernando de Ory, Virgilio Carreño, Rubén del Campo and SIELTEC Canarias is acknowledged.

Edited by: T. Petäjä

\section{References}

Asmi, A., Collaud Coen, M., Ogren, J. A., Andrews, E., Sheridan, P., Jefferson, A., Weingartner, E., Baltensperger, U., Bukowiecki, N., Lihavainen, H., Kivekäs, N., Asmi, E., Aalto, P. P., Kulmala, M., Wiedensohler, A., Birmili, W., Hamed, A., O’Dowd, C., G Jennings, S., Weller, R., Flentje, H., Fjaeraa, A. M., Fiebig, M., Myhre, C. L., Hallar, A. G., Swietlicki, E., Kristensson, A., and Laj, P.: Aerosol decadal trends - Part 2: In-situ aerosol particle number concentrations at GAW and ACTRIS stations, Atmos. Chem. Phys., 13, 895-916, doi:10.5194/acp-13-895-2013, 2013.

Birmili, W. and Wiedensohler, A.: New particle formation in the continental boundary layer: Meteorological and gas phase parameter influence, Geophys. Res. Lett., 27, 3325-3328, doi:10.1029/1999GL011221, 2000.

Boulon, J., Sellegri, K., Venzac, H., Picard, D., Weingartner, E., Wehrle, G., Collaud Coen, M., Bütikofer, R., Flückiger, E., Baltensperger, U., and Laj, P.: New particle formation and ultrafine charged aerosol climatology at a high altitude site in the Alps (Jungfraujoch, $3580 \mathrm{~m}$ a.s.1., Switzerland), Atmos. Chem. Phys., 10, 9333-9349, doi:10.5194/acp-10-9333-2010, 2010.

Boulon, J., Sellegri, K., Hervo, M., Picard, D., Pichon, J.-M., Fréville, P., and Laj, P.: Investigation of nucleation events vertical extent: a long term study at two different altitude sites, Atmos. Chem. Phys., 11, 5625-5639, doi:10.5194/acp-11-56252011, 2011.

Boy, M. and Kulmala, M.: Nucleation events in the continental boundary layer: Influence of physical and meteorological param- eters, Atmos. Chem. Phys., 2, 1-16, doi:10.5194/acp-2-1-2002, 2002.

Boy, M., Karl, T., Turnipseed, A., Mauldin, R. L., Kosciuch, E., Greenberg, J., Rathbone, J., Smith, J., Held, A., Barsanti, K., Wehner, B., Bauer, S., Wiedensohler, A., Bonn, B., Kulmala, M., and Guenther, A.: New particle formation in the Front Range of the Colorado Rocky Mountains, Atmos. Chem. Phys., 8, 15771590, doi:10.5194/acp-8-1577-2008, 2008.

Dal Maso, M., Kulmala M., Riipinen, I., Wagner, R., Hussein, T., Aalto, P. P., and Lehtinen, K. E. J.: Formation and growth of freshatmospheric aerosols: eight years of aerosol size distribution data from SMEAR II, Hyytiälä, Finland, Boreal Environ. Res., 10, 323-336, 2005.

García, R. D.: Aplicación de modelos de transferencia radiativa para el control operativo del programa BSRN (Base-line Surface Radiation Network) del Centro de Investigación Atmosférica de Izaña, PhD Thesis, University of Valladolid at Spain, December, 2011.

García, R. D., García, O. E., Cuevas, E., Cachorro, V., RomeroCampos, P. M., Ramos, R., and de Frutos, A. M.: Solar radiation measurements compared to simulations at the BSRN Izaña station. Mineral dust radiative forcing and efficiency study, J. Geophys. Res., 119,, 179-194, doi:10.1002/2013JD020301, 2014

Gómez-Moreno, F. J., Alonso, E., Artiñano, B., Juncal Bello, V., Piñeiro Iglesias, M., López Mahía, P., Pérez, N., Pey, J., Alastuey, A., de la Morena, B. A., García, M. I., Rodríguez, S., Sorribas, M., Titos, G., Lyamani, H., and Alados-Arboledas, L.: The Spanish network on environmental DMAs: the 2012 SMPS+UFP intercomparison campaign and study on particle losses in dryers, European Aerosol Conference, Prague, 1-6 September, 2013.

Hallar, A. G., Lowenthal, D. H., Chirokova, G., Borys, R. D., and Wiedinmyer, C.: Persistent daily new particle formation at a mountain-top location, Atmos. Environ., 45, 4111-4115, 2011.

Hamed, A., Joutsensaari, J., Mikkonen, S., Sogacheva, L., Dal Maso, M., Kulmala, M., Cavalli, F., Fuzzi, S., Facchini, M. C., Decesari, S., Mircea, M., Lehtinen, K. E. J., and Laaksonen, A.: Nucleation and growth of new particles in Po Valley, Italy, Atmos. Chem. Phys., 7, 355-376, doi:10.5194/acp-7-355-2007, 2007.

Held, A., Nowak, A., Birmili, W., Wiedensohler, A., Forkel, R., and Klemm, O.: Observations of particle formation and growth in a mountainous forest region in central Europe, J. Geophys. Res., 109, 1-9, doi:10.1029/2004JD005346, 2004.

Hinds, W. C.: Aerosol Technology, Properties behaviour and measurements of airborne particles, Wiley-Interscience, John Wiley \& Sons, Inc. Canada, 1999.

IPCC: Climate Change 2007, The Physical Science Basis, Contribution of Working Group I to the Fourth Assessment Report of the Intergovernmental Panel on Climate Change, Cambridge University Press, New York, 2007.

Järvinen, E., Virkkula, A., Nieminen, T., Aalto, P. P., Asmi, E., Lanconelli, C., Busetto, M., Lupi, A., Schioppo, R., Vitale, V., Mazzola, M., Petäjä, T., Kerminen, V.-M., and Kulmala, M.: Seasonal cycle and modal structure of particle number size distribution at Dome C, Antarctica, Atmos. Chem. Phys., 13, 7473-7487, doi:10.5194/acp-13-7473-2013, 2013.

Kleissl, J., Honrath, R. E., Dziobak, M. P., Tanner, D., Val Martín, M., Owen, R. C., and Helmig, D.: Occurrence of upslope flows at the Pico mountaintop observatory: A case study of orographic 
flows on a small, volcanic island, J. Geophys. Res., 112, D10S35, doi:10.1029/2006JD007565, 2007

Kulmala, M.: How Particles Nucleate and Grow, Science, 302, 1001001, 2003.

Kulmala, M. and Kerminen, V. M.: On the formation and growth of Atmospheric nanoparticles, Atmos. Res., 90, 132-150, 2008.

Kulmala, M., Vehkamäki, H., Petäjä, T., Dal Maso, M., Lauri, A., Kerminen, V.-M., Birmili, W., and McMurry, P. H.: Formation and growth rates of ultrafine atmospheric particles: a review of observations, J. Aerosol Sci., 35, 143-176, doi:10.1016/j.jaerosci.2003.10.003, 2004.

Kulmala, M., Lehtinen, K. E. J., and Laaksonen, A.: Cluster activation theory as an explanation of the linear dependence between formation rate of $3 \mathrm{~nm}$ particles and sulphuric acid concentration, Atmos. Chem. Phys., 6, 787-793, doi:10.5194/acp-6-787-2006, 2006.

Kulmala, M., Petäjä, T., Nieminen, T., Sipilä, M., Manninen, H. E., Lehtipalo, K., Dal Maso, M., Aalto, P. P., Junninen, H., Paasonen, P., Riipinen, I., Lehtinen, K. E. J., Laaksonen, A., and Kerminen, V.-M.: Measurement of the nucleation of atmospheric aerosol particles, Nat. Protoc., 7, 1651-1667, 2012.

Kulmala, M., Kontkanen, J., Junninen, H., Lehtipalo, K., Manninen, H.E., Nieminen, T., Petäjä, T., Sipilä, M., Schobesberger, S., Rantala, P., Franchin, A., Jokinen, T., Järvinen, E., Äijälä, M., Kangasluoma, J., Hakala, J., Aalto, P. P., Paasonen, P., Mikkilä, J., Vanhanen, J., Aalto, J., Hakola, H., Makkonen, U., Ruuskanen, T., Mauldin, R. L., Duplissy, J., Vehkamäki, H., Bäck, J., Kortelainen, A., Riipinen, I., Kurtán, T., Johnston, M. V., Smith, J. N., Ehn, M., Mentel, T. F., Lehtinen, K. E. J., Laaksonen, A., Kerminen, V.-M., and Worsnop, D. R.: Direct observations of atmospheric aerosol nucleation, Science, 339, 943-946, doi:10.1126/science.1227385, 2013.

Laakso, L., Anttila, T., Lehtinen, K. E. J., Aalto, P. P., Kulmala, M., Hõrrak, U., Paatero, J., Hanke, M., and Arnold, F.: Kinetic nucleation and ions in boreal forest particle formation events, Atmos. Chem. Phys., 4, 2353-2366, doi:10.5194/acp-4-2353-2004, 2004.

Laaksonen, A., Kulmala, M., O’Dowd, C. D., Joutsensaari, J., Vaattovaara, P., Mikkonen, S., Lehtinen, K. E. J., Sogacheva, L., Dal Maso, M., Aalto, P., Petäjä, T., Sogachev, A., Yoon, Y. J., Lihavainen, H., Nilsson, D., Facchini, M. C., Cavalli, F., Fuzzi, S., Hoffmann, T., Arnold, F., Hanke, M., Sellegri, K., Umann, B., Junkermann, W., Coe, H., Allan, J. D., Alfarra, M. R., Worsnop, D. R., Riekkola, M.-L., Hyötyläinen, T., and Viisanen, Y.: The role of VOC oxidation products in continental new particle formation, Atmos. Chem. Phys., 8, 2657-2665, doi:10.5194/acp-82657-2008, 2008.

Manninen, H. E., Nieminen, T., Asmi, E., Gagné, S., Häkkinen, S., Lehtipalo, K., Aalto, P., Vana, M., Mirme, A., Mirme, S., Hõrrak, U., Plass-Dülmer, C., Stange, G., Kiss, G., Hoffer, A., Törö, N., Moerman, M., Henzing, B., de Leeuw, G., Brinkenberg, M., Kouvarakis, G. N., Bougiatioti, A., Mihalopoulos, N., O’Dowd, C., Ceburnis, D., Arneth, A., Svenningsson, B., Swietlicki, E., Tarozzi, L., Decesari, S., Facchini, M. C., Birmili, W., Sonntag, A., Wiedensohler, A., Boulon, J., Sellegri, K., Laj, P., Gysel, M., Bukowiecki, N., Weingartner, E., Wehrle, G., Laaksonen, A., Hamed, A., Joutsensaari, J., Petäjä, T., Kerminen, V.-M., and Kulmala, M.: EUCAARI ion spectrometer measurements at 12 European sites - analysis of new particle formation events,
Atmos. Chem. Phys., 10, 7907-7927, doi:10.5194/acp-10-79072010, 2010.

McFiggans, G., Artaxo, P., Baltensperger, U., Coe, H., Facchini, M. C., Feingold, G., Fuzzi, S., Gysel, M., Laaksonen, A., Lohmann, U., Mentel, T. F., Murphy, D. M., O’Dowd, C. D., Snider, J. R., and Weingartner, E.: The effect of physical and chemical aerosol properties on warm cloud droplet activation, Atmos. Chem. Phys., 6, 2593-2649, doi:10.5194/acp-6-2593-2006, 2006.

Metzger, A., Verheggen, B., Dommen, J., Duplissy, J., Prevot, A. S. H., Weingartner, E., Riipinen, I., Kulmala, M., Spracklen, D. V., Carslaw, K. S., and Baltensperger, U.: Evidence for the role of organics in aerosol particle formation under atmospheric conditions, P. Natl. Acad. Sci. USA, 107, 6646-6651, doi:10.1073/pnas.0911330107, 2010.

Neitola, K., Asmi, E., Komppula, M., Hyvärinen, A.-P., Raatikainen, T., Panwar, T. S., Sharma, V. P., and Lihavainen, H.: New particle formation infrequently observed in Himalayan foothills - why?, Atmos. Chem. Phys., 11, 8447-8458, doi:10.5194/acp-11-8447-2011, 2011.

Nieminen, T., Lehtinen, K. E. J., and Kulmala, M.: Sub-10 nm particle growth by vapor condensation - effects of vapor molecule size and particle thermal speed, Atmos. Chem. Phys. 10, 9773 9779, doi:10.5194/acp-10-9773-2010, 2010.

Nishita, C., Osada, K., Kido, M., Matsunaga, K., and Iwasaka, Y.: Nucleation mode particles in upslope valley winds at Mount Norikura, Japan: Implications for the vertical extent of new particle formation events in the lower troposphere, J. Geophys. Res., 113, D06202, doi:10.1029/2007JD009302, 2008.

Parrish, D. D. and Fehsenfeld, F. C.: Methods for gas-phase measurements of ozone, ozone precursors and aerosol precursors, Atmos. Environ., 34, 1921-1957, 2000.

Petäjä, T., Mauldin III, R. L., Kosciuch, E., McGrath, J., Nieminen, T., Boy, M., Adamov, A., Kotiaho, T., and Kulmala, M.: Sulfuric acid and $\mathrm{OH}$ concentrations in a boreal forest site, Atmos. Chem. Phys., 9, 7435-7448, doi:10.5194/acp-9-7435-2009, 2009.

Rodríguez, S., Van Dingenen, R., Putaud, J. P., Martins-Dos Santos, S., and Roselli, D.: Nucleation and growth of new particles in the rural atmosphere of Northern Italy - Relationship to air quality monitoring, Atmos. Environ., 39, 6734-6746, 2005.

Rodríguez, S., González, Y., Cuevas, E., Ramos, R., Romero, P. M., Abreu-Afonso, J., and Redondas, A.: Atmospheric nanoparticle observations in the low free troposphere during upward orographic flows at Izaña Mountain Observatory, Atmos. Chem. Phys., 9, 6319-6335, doi:10.5194/acp-9-6319-2009, 2009.

Rodríguez, S., Alastuey, A., Alonso-Pérez, S., Querol, X., Cuevas, E., Abreu-Afonso, J., Viana, M., Pérez, N., Pandolfi, M., and de la Rosa, J.: Transport of desert dust mixed with North African industrial pollutants in the subtropical Saharan Air Layer, Atmos. Chem. Phys., 11, 6663-6685, doi:10.5194/acp-11-66632011, 2011.

Salma, I., Borsós, T., Weidinger, T., Aalto, P., Hussein, T., Dal Maso, M., and Kulmala, M.: Production, growth and properties of ultrafine atmospheric aerosol particles in an urban environment, Atmos. Chem. Phys., 11, 1339-1353, doi:10.5194/acp-111339-2011, 2011.

Shaw, G. E.: Aerosols at a mountaintop observatory in Arizona, J. Geophys. Res., 112, D07206, doi:10.1029/2005JD006893, 2007.

Steinbacher, M., Zellweger, C., Schwarzenbach, B., Bugmann, S., Buchmann, B., Ordóñez, C., Prevot, A. S. H., and Hueglin, C., 
Nitrogen oxide measurements at rural sites in Switzerland: Bias of conventional measurement techniques, J. Geophys. Res., 112, D11307, doi:10.1029/2006JD007971, 2007.

Venzac, H., Sellegri, K., and Laj, P.: Nucleation events detected at the high altitude site of the Puy de Dôme research station, France, Bor. Environ. Res., 12, 345-359, 2007.

Venzac, H., Sellegri, K., Laj, P., Villani, P., Bonasoni, P., Marioni, A., Cristofanelli, P., Calzolari, F., Fuzzi, S., Decesari, S., Facchini, M.-C., Vuillermoz, E., and Verza, G.-P.: High frequency new particle formation in the Himalayas, P. Natl. Acad. Sci. USA, 105, 15666-15671, 2008.

Weber, J. R., McMurry, P. H., Eisele, F. L., and Tanner, D. J.: Measurements of expected nucleation precursors species and 3$500 \mathrm{~nm}$ diameter particles at Mauna Loa, Hawaii, J. Atmos. Sci., 52, 2242-2257, 1995.

Weber, J. R., McMurry, P. H., Mauldin III, R. L., Tanner, D. J., Eisele, F. L., Clarke, A. D., and Kapustin, V. N.: New particle formation in the remote troposphere: a comparison of observations at various sites, Geophys. Res. Lett., 26, 307-310, 1999.
Yli-Juuti, T., Riipinen, I., Aalto, P. P., Nieminen, T., Maenhaut, W., Janssens, I. A., Claeys, M., Salma, I., Ocskay, R., Hoffer, A., Imre, K., and Kulmala, M.: Characteristics of new particle formation events and cluster ions at K-puszta, Hungary, Boreal Environ. Res., 14, 683-698, 2009.

Yli-Juuti, T., Nieminen, T., Hirsikko, A., Aalto, P. P., Asmi, E., Hõrrak, U., Manninen, H. E., Patokoski, J., Dal Maso, M., Petäjä, T., Rinne, J., Kulmala, M., and Riipinen, I.: Growth rates of nucleation mode particles in Hyytiälä during 20032009: variation with particle size, season, data analysis method and ambient conditions, Atmos. Chem. Phys., 11, 12865-12886, doi:10.5194/acp-11-12865-2011, 2011. 